\title{
An approach for evaluating the bioavailability and risk assessment of potentially toxic elements using edible and inedible plants-the Remance (Panama) mining area as a model
}

\author{
Ana Cristina González-Valoys $(\mathbb{D} \cdot$ José Ulises Jiménez Salgado • Rita Rodríguez • \\ Tisla Monteza-Destro • Miguel Vargas-Lombardo • Eva María García-Noguero • \\ José María Esbrí • Raimundo Jiménez-Ballesta • Francisco Jesús García-Navarro • \\ Pablo Higueras
}

Received: 1 June 2021/Accepted: 31 August 2021/Published online: 22 October 2021

(C) The Author(s) 2021

\begin{abstract}
Mining affects the environment, particularly through the persistence of accumulation of tailings materials; this is aggravated under tropical climatic conditions, which favours the release of potentially toxic elements (PTEs) bioavailable to the local flora and fauna and supposing a risk to human health. The Remance gold mine (Panamá), exploited intermittently for more than 100 years, and has remained derelict for over 20 years. Within the area live farmers who carry out subsistence agriculture and livestock activities. The objective of this study has
\end{abstract}

Supplementary Information The online version contains supplementary material available at https://doi.org/10.1007/ s10653-021-01086-8.

A. C. González-Valoys

Centro Experimental de Ingeniería, Technological University of Panama, Vía Tocumen,

0819-07289 Panama City, Panama

A. C. González-Valoys · E. M. García-Noguero J. M. Esbrí · P. Higueras Instituto de Geología Aplicada, Castilla-La Mancha University, EIMI Almadén. Plaza Manuel Meca 1, Almadén, 13400 Ciudad Real, Spain

A. C. González-Valoys $(\varangle) \cdot$ R. Jiménez-Ballesta Department of Geology \& Geochemistry, Autonomous University of Madrid, University City of Cantoblanco, 28049 Madrid, Spain

e-mail: ana.gonzalez1@utp.ac.pa been to study the transference of PTEs in the local agricultural soil-plants system, with the goal of identifying their bioavailability to perform a human risk assessment. The results obtained of the Bioaccumulation coefficient in local plants show very weak to strong absorption of As $(<0.001-1.50), \quad \mathrm{Hg}$ $(<0.001-2.38), \mathrm{Sb}(0.01-7.83), \mathrm{Cu}(0.02-2.89)$, and $\mathrm{Zn} \mathrm{(0.06-5.32).} \mathrm{In} \mathrm{the} \mathrm{case} \mathrm{of} \mathrm{Cu}$ in grass $\left(18.3 \mathrm{mg} \mathrm{kg}^{-1}\right)$ and plants $\left(16.9 \mathrm{mg} \mathrm{kg}^{-1}\right)$ the concentrations exceed the maximum authorised value in animal nutrition for ruminants $\left(10 \mathrm{mg} \mathrm{kg}^{-1}\right)$. The risk to human health for edible plants exceeds the noncarcinogenic risk for rice, corn, cassava, and tea leaves for Sb (HQ 19.450, 18.304, 6.075, 1.830, respectively), the carcinogenic risk for $\mathrm{Cu}$

\footnotetext{
J. U. Jiménez Salgado

Centro de Investigaciones Hidráulicas e Hidrotécnicas, Technological University of Panama, Ricardo J. Alfaro Avenue, Dr. Víctor Levi Sasso University Campus, 0819-07289 Panama City, Panama

R. Rodríguez

Dirección de Investigación, Vicerrectoría de Investigación, Postgrado y Extensión, Technological University of Panama, Ricardo J. Alfaro Avenue, Dr. Víctor Levi Sasso University Campus, 0819-07289 Panama City, Panama
} 
$\left(\mathrm{CR}=2.3 \times 10^{-3}, \quad 7.7 \times 10^{-4}, \quad 1.1 \times 10^{-3}\right.$, $1.0 \times 10^{-3}$, respectively), and the carcinogenic risk for As in rice, corn and tea leaves $\left(\mathrm{CR}=8 \times 10^{-5}\right.$, $3 \times 10^{-5}, 3 \times 10^{-5}$, respectively). Urgent measures are needed to alleviate these effects.

Keywords Potentially toxic elements (PTEs) . Plants · Bioavailability · Risk assessment · Food

\section{Introduction}

Soil quality is affected by the presence of PTEs, which is largely due to anthropogenic activity (Bravo et al., 2017; Hooda, 2010; Rogival et al., 2007; Zhuang et al., 2009). Mining activity strongly impacts the environment because it implies exposing the minerals that contain PTEs to atmospheric conditions (Kamunda et al., 2016; Palansooriya et al., 2020). In particular, abandoned mining tailings become sources of environmental contamination (Chaabani et al., 2017; Kaninga et al., 2020; Santos et al., 2016) when they are exposed to environmental conditions like rain and wind, which influences the entire food chain from soils to plants and animals and, directly or indirectly, to human beings (Getaneh \& Alemayehu, 2006).

For example, $\mathrm{Cu}$ is an essential micronutrient, which participates in the transfer of electrons, but it

T. Monteza-Destro

Departamento de Geotecnia, Facultad de Ingeniería Civil, Technological University of Panama, Ricardo J. Alfaro Avenue, Dr. Víctor Levi Sasso University Campus, 0819-07289 Panama City, Panama

\section{Vargas-Lombardo}

Facultad de Ingeniería de Sistemas Computacionales, Technological University of Panama, Ricardo J. Alfaro Avenue, Dr. Víctor Levi Sasso University Campus, 0819-07289 Panama City, Panama

M. Vargas-Lombardo

SNI-SENACYT Sistema Nacional de Investigación-

Secretaria Nacional de Ciencia, Tecnología e Innovación, Clayton, Ciudad del Saber Edif.205,

0816-02852 Panama City, Panama

\section{F. J. García-Navarro}

Escuela Técnica Superior de Ingenieros Agrónomos de Ciudad Real, Castilla-La Mancha University, Ronda de Calatrava $\mathrm{n}^{\circ}$ 7, 13071 Ciudad Real, Spain can be toxic to plants and humans in large quantities (Bravo et al., 2015; Gómez-Armesto et al., 2015). Zn is linked with enzymes and participates in three plant functions: catalytic, coercive, and structural (Bravo et al., 2015). Ba is the trace element found at the highest concentrations in soil (Bravo et al., 2015), while $\mathrm{Sb}, \mathrm{As}$ and $\mathrm{Hg}$ are non-essential trace elements. All these elements are named by Hooda, (2010) as PTEs, whose presence in soil poses a serious soil quality problem and a human health risk (Rascio and Navari-Izo, 2011; Sun et al., 2018).

The concentration of PTEs in plants depends on several factors, such as abundance and speciation ((bio)availability) in soil, type of plant and its age, depth of roots, among others (Cunha et al., 2014). The ability of plants to take up nutrients can be measured by the bioaccumulation coefficient (BAC), which is calculated as the ratios between the concentration of the element in a plant (any plant tissue, e.g., root, leaf, or fruit) and its content in soil (Kabata-Pendias, 2011; Cunha et al., 2014; Bravo et al., 2017), to observe the element's bioavailability in soil (Bravo et al., 2017). The bioaccumulation coefficient (BAC) applied to PTEs describes the transfer from soil to plants, while the bioconcentration coefficient (BC) describes a plant's ability to adsorb PTEs from soil when they appear in an available form (Gruszecka-Kosowska, 2020).

Many plants are used for direct human consumption as they form part of the population's diet, such as fruit and cereals. The human health risk posed by eating them as part of their daily diet can be assessed and determined by calculating the non-carcinogenic and carcinogenic risks of the PTEs they contain (Gruszecka-Kosowska, 2019, 2020). Eating plants can also affect human beings indirectly via ruminant animals because they form part of the food chain and can also affect ruminant animals' health (Aquilina et al., 2016; Pareja-Carrera et al., 2021).

According to the World Population Prospects, each state should promote its own research in relation to their agricultural regions and agroecosystems (UN, 2015). The National Secretary of Science and Technology (SENACYT) and the Institute for the Training and Use of Human Resources (IFARHU) of Panama promote a project in the abandoned Remance gold mine, where tailings are exposed to the climate conditions of wind and rain, which can affect surrounding soils and plants. The peasants who live 
within the old mine perimeter grow products for their own consumption and graze livestock, even in those areas very close to tailings. The objective of this study was to analyse the degree that mining activity affected flora in relation to the concentration of PTEs and their bioavailability by bearing in mind the human risk assessment and evaluating the health risk.

\section{Materials and methods}

Study area

The Remance gold mine is located in the village of Remance, a district of San Francisco, in the Veraguas province in the Republic of Panama, Central America. From a geological point of view, a hydrothermal alteration covers an area of some $10 \mathrm{~km}^{2}$, and the epithermal gold deposit is hosted on a bed of pyroclastic rocks (Nelson \& Ganoza, 1999). The gold deposit comprises a system of veins in which the principal vein contains the largest ore quantities, along with minor, but still relevant, veins like Santa Rosa and Consuelo, which are subterranean and have sporadic outcrops (Nelson \& Ganoza, 1999).

The mine has been exploited intermittently by different companies for over 200 years, between 1800 and 1998. The last exploitation company was "Minera Remance S.A", which operated the mine between 1989 and 1999 (Nelson \& Ganoza, 1999) by applying the cyanidation process to extract precious metal (Gómez, 2008). Nowadays the mine is abandoned, and there are still three tailing ponds with mining waste exposed to environmental conditions, which could be sources of pollution for soils, water bodies, and flora (González-Valoys et al., 2021a).

According to the Köppen climate classification map, the climate in the study area corresponds to the Ami type. It is a humid tropical climate, with the influence of monsoons, and an annual rainfall of $>$ $2,250 \mathrm{~mm}$ that concentrates $(60 \%)$ in the four wettest months (August-November). The rain rates of dry months (January-March) drop below $60 \mathrm{~mm}$, and the average temperature of the coolest month is $>18{ }^{\circ} \mathrm{C}$ (Dirección de Meteorología de ETESA, 2007).

Pasture predominates in the old mine area, with stubble and shrubby vegetation no higher than $5 \mathrm{~m}$ and a few small mixed broadleaf forest patches. Some small settlements are found in the area, and the commonest annual crops are rice, sugarcane, and corn (Ministerio de Ambiente Panamá, 2012), as well as other crops like cassava, banana, beans, among others. Cattle raising and horse grazing are also observed.

\section{Sampling}

Plant sampling was performed between May and June 2019, and in January 2020. Table 1 offers the collected samples, together with their common name, family, taxa and frequency for 75 samples, Table ST1 presents the coordinates. The location map of the samples appears in Fig. 1. The studied tissue was either leaves or edible plant parts. Together with each plant, a soil sample was collected to determine the BAC to evaluate the transfer of PTEs from soil to plants, and the available fraction was noted to evaluate the $\mathrm{BC}$.

The edible part was taken from edible plants, while 30-40 leaves were collected from the rest of the plant as composite samples using gloves and scissors. Samples were placed in a paper envelope and stored at room temperature before being analysed. Soil samples were collected at $0-30 \mathrm{~cm}$ deep inside a PVC tube, which was placed inside soil to obtain samples (González-Valoys et al., 2021b). Soil samples (approx. $3 \mathrm{~kg}$ each) were placed in a plastic bag using a plastic shovel to be stored at ambient temperature.

Processing and analysing samples

Leaf samples were washed with deionised water to eliminate dust impurities, were left at ambient temperature for 4 days and then left to dry for 3 more days at $36{ }^{\circ} \mathrm{C}$ in a stove. Finally, samples were crushed by a domestic grinder to increase homogeneity. In the same way, soil samples were dried at ambient temperature, disaggregated with the help of a manual roller and sieved to less than $2 \mathrm{~mm}$. The aliquots taken for the analysis $(50 \mathrm{~g})$ were further ground in an agate mortar until the diameter of the material was below $100 \mu \mathrm{m}$.

The elements $\mathrm{Cu}, \mathrm{Zn}, \mathrm{As}, \mathrm{Ba}, \mathrm{Sb}$, and T-Hg were studied because in a previous study of the tailings from the abandoned gold mine, they are the PTEs that were above the value of the Panama soil standard (González-Valoys et al., 2021a). The $\mathrm{Cu}, \mathrm{Zn}, \mathrm{As}, \mathrm{Sb}$, and $\mathrm{Ba}$ determinations were made in both sample kinds, namely plants pressed into tablets and soil in a powder form, by energy dispersion X-ray fluorescence spectroscopy (ED-XRF) in Epsilon One equipment 
Table 1 plant samples taken for the study. Edible plants in bold. The common names in italics are in Spanish

\begin{tabular}{|c|c|c|c|}
\hline Family & Taxon & Common name & Frequency \\
\hline Anacardiaceae & Anacardium excelsum (Bertero \& Balb. ex Kunth) Skeels & Espavé & 3 \\
\hline Annonaceae & Xylopia frutescens Aubl & Malagueto macho & 4 \\
\hline Araceae & morphospecies & - & 1 \\
\hline Araliaceae & Schefflera morototoni (Aubl.) Maguire, Steyerm. \& Frodin & Mangabe & 1 \\
\hline Asteraceae & Baccharis trinervis Pers & - & 1 \\
\hline Asteraceae & Ayapana stenolepis (Steetz) R.M. King \& H. Rob & Tea leaves & 1 \\
\hline Bombacaceae & Pseudobombax septenatum (Jacq.) Dugand & Barrigón & 2 \\
\hline Boraginaceae & Heliotropium indicum $L$ & Turnsole, indian heliotrope & 2 \\
\hline Burseraceae & Bursera simaruba (L.) Sarg & Indio desnudo & 2 \\
\hline Clusiaceae & Garcinia madruno (Kunth) Hammel & Satro & 1 \\
\hline Connaraceae & Cnestidium rufescens Planch & - & 1 \\
\hline Convolvulaceae & Ipomoea batatas (L.) Lam & Yam or sweet potato & 1 \\
\hline Cyperaceae & Rhynchospora cephalotes (L.) Vahl & Grass & 2 \\
\hline Dennstaedtiaceae & Pteridium caudatum (L.) Maxon & Fern & 2 \\
\hline Dilleniaceae & Curatella americana $\mathrm{L}$ & Chumico & 4 \\
\hline Euphorbiaceae & Mabea occidentalis Benth & Caciquillo & 2 \\
\hline Euphorbiaceae & Manihot esculenta Crantz & Cassava, yuca & 1 \\
\hline Fabaceae-Mimosoideae & Acacia mangium Willd & Acacia & 1 \\
\hline Fabaceae-Mimosoideae & Acacia sp. & Acacia & 1 \\
\hline Fabaceae-Mimosoideae & Calliandra magdalenae (Bertero ex DC.) Benth & - & 1 \\
\hline Fabaceae-Mimosoideae & Cojoba rufescens (Benth.) Britton \& Rose & Coralillo & 1 \\
\hline Fabaceae-Mimosoideae & Zygia longifolia (Humb. \& Bonpl. ex Willd.) Britton \& Rose & Pichindé & 1 \\
\hline $\begin{array}{l}\text { Fabaceae- } \\
\quad \text { Papilionoideae }\end{array}$ & Andira inermis (W. Wright) Kunth ex DC & Harino & 4 \\
\hline Gleicheniaceae & Dicranopteris pectinata (Willd.) Underw & Fern & 1 \\
\hline Lauraceae & Nectandra sp. & Sigua & 1 \\
\hline Lygodiaceae & Lygodium venustum $\mathrm{Sw}$ & Crespillo & 2 \\
\hline Malpighiaceae & Byrsonima crassifolia (L.) Kunth & Nance & 2 \\
\hline Malvaceae & Guazuma ulmifolia Lam & Guácimo & 3 \\
\hline Malvaceae & mophospecies & - & 3 \\
\hline Melastomataceae & Miconia argentea (Sw.) DC & Papelillo & 1 \\
\hline Melastomataceae & Mouriri myrtilloides (Sw.) Poir & & 1 \\
\hline Moraceae & Brosimum alicastrum $\mathrm{Sw}$ & Berba, cacique, breadnut & 1 \\
\hline Myrtaceae & Eugenia sp. & Guayabillo & 1 \\
\hline Piperaceae & Piper leptocladum C. DC & Cordoncillo & 1 \\
\hline Poaceae & morphospecies & Grass, pasto & 12 \\
\hline Poaceae & Oryza sativa $\mathbf{L}$ & Rice, arroz & 1 \\
\hline Poaceae & Zea mays $\mathbf{L}$ & Corn, maiź & 1 \\
\hline Rubiaceae & Alibertia edulis (Rich.) A. Rich & Trumpet & 1 \\
\hline Rubiaceae & Declieuxia fruticosa (Willd.) Kuntze & Tea leaves & 1 \\
\hline Rubiaceae & Genipa americana $\mathrm{L}$ & Jagua & 1 \\
\hline Sapindaceae & Cupania americana $L$ & Gorgojo, weevil & 1 \\
\hline
\end{tabular}




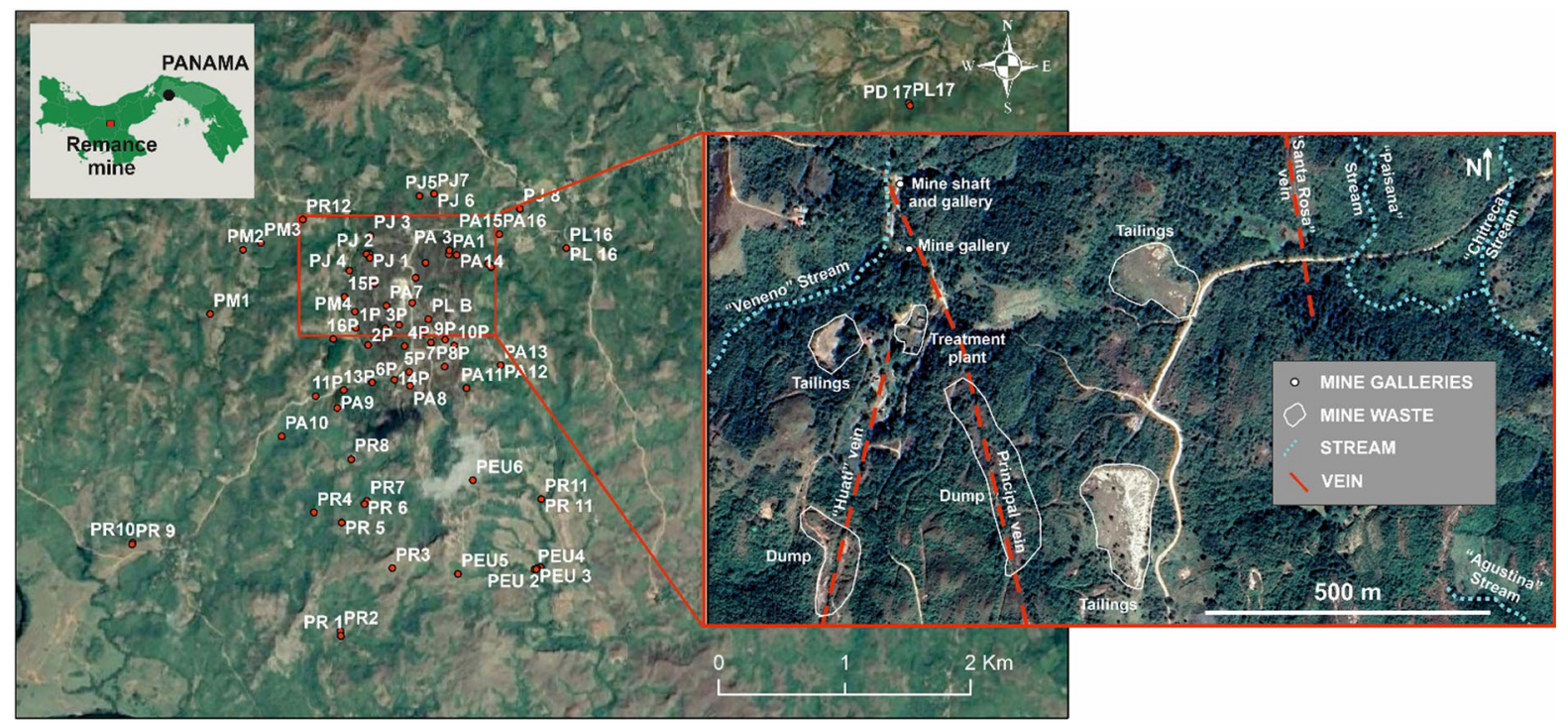

Fig. 1 Location map of the plant samples taken within the Remance gold mine perimeter

(PANalytical brand). Total Hg (T-Hg) was determined by Zeeman atomic absorption spectroscopy with highfrequency modulation of light polarisation (ZAASHFM) using commercial equipment Lumex RA915 M with a pyrolytic attachment (PYRO-915 +). Certified reference materials were used to check both precision and accuracy: NIST 2710A (Montana soil) and LGC7162 (strawberry leaves). Recovery percentages between 80 and 100\% (ED-XRF) and 95-100\% (ZAAS-HF) were obtained.

Based on high As and $\mathrm{Cu}$ concentrations determined by the ED-FRX analysis, a set of 12 soil samples was selected to evaluate the BC. In this way, the sequential extraction in three stages proposed by the European Community Bureau of Reference (BCR) was carried out in accordance with the procedure described by Sahuquillo et al., (1999): in step 1 (S1) the exchangeable and bound to carbonates fraction is extracted with acetic acid; in step 2 (S2) the reducible fraction (bound to $\mathrm{Fe}$ and $\mathrm{Mn}$ oxides), is extracted with hydroxylamine hydrochloride; and in step 3 (S3) the oxidizable fraction (bound to organic matter and sulphides) is extracted using a digestion with hydrogen peroxide first and then ammonium acetate. This method is widely used for evaluating the fractionation of metals and has been applied to study a wide variety of solid samples, including different mining waste types (Marguí et al., 2006; García-Ordiales et al., 2019). Hence, the first three fractions were considered potentially labile or reactive fraction plant uptake or bioaccessible to humans (Kelepertzis \& Stathopoulou, 2013; Madrid et al., 2007).

Measurements of $\mathrm{Cu}$ and As in the BCR extracts were taken by high-resolution atomic absorption spectroscopy (HR-AAS) in ContrAA-800 equipment (Analytik Jena brand) using the flame and the graphite furnace techniques, respectively. Samples were also subjected to microwave-assisted acid digestion with aqua regia according to EPA method 3051A (USEPA, 2007) to analyse pseudo-total concentrations (Higueras et al., 2017; Melaku et al., 2005). In all cases, solutions were filtered with Whatman filters $(8 \mu \mathrm{m})$. As a quality control of total contents, analyses of blanks and random duplicates were performed. Certified reference material NIST 2710A was also digested and analysed in triplicate, with $95 \%$ and $98 \%$ recovery for $\mathrm{Cu}$ and $\mathrm{As}$, respectively. Blanks and certified reference material BCR 701 were also used in the BCR extractions with recoveries between 95 and $102 \%$ for $\mathrm{Cu}$ (As is not certificated in this reference material).

Soil to plant transfer indices

Two indices were used to determine the transfer of PTEs from soil to plant: BAC and BC. The BAC is a key component for quantifying differences in metal bioavailability by describing the transfer of PTEs from 
soil to plant (Gruszecka-Kosowska, 2019; Inacio et al., 2014). The ratios between the concentration of the element in the plant and the element concentration in soil was calculated (Bravo et al., 2015; KabataPendias, 2011).

$\mathrm{BAC}=\mathrm{C}_{\text {leaves or edible part plant }} / \mathrm{C}_{\text {soil }}$

where $\mathrm{C}_{\text {leaves or edible part plant }}$ is the concentration of a particular PTE $\left(\mathrm{mg} \mathrm{kg}^{-1}\right)$ in the leaves or edible part of the plant, and $\mathrm{C}$ soil is the total concentration of a particular PTE in soil samples $\left(\mathrm{mg} \mathrm{kg}^{-1}\right)$.

Bioconcentration coefficient $(B C)$ : describes the plant's capacity to adsorb PTEs from soil when PTEs appear in an available form (Gruszecka-Kosowska, 2019; Inacio et al., 2014). BC is calculated as the ratios between the PTE concentration in leaves or edible parts and the available concentrations of PTE in soil (Wang et al., 2006):

$\mathrm{BC}=\mathrm{C}_{\text {leaves or edible part plant }} / \mathrm{C}_{\text {soil available }}$

where $\mathrm{C}_{\text {leaves or edible part plant }}$ is the concentration of a particular PTE $\left(\mathrm{mg} \mathrm{kg}^{-1}\right)$ in the leaves or the edible part plant and $\mathrm{C}_{\text {soil available is the concentration of a }}$ particular PTE in soil samples $\left(\mathrm{mg} \mathrm{kg}^{-1}\right)$ obtained from the BCR three-stage sequential extraction procedure because it is considered potentially labile or the reactive fraction plant uptake (Kelepertzis \& Stathopoulou, 2013; Madrid et al., 2007).

Human health risk assessment

This assessment was performed by the following parameters: daily intake rate (DIR), average daily dose (ADD), hazard quotient (HQ), and carcinogenic risk (CR).

Daily intake rate (DIR) was calculated as the sum of consumed food (Gruszecka-Kosowska, 2019; WHO, 2005) which, in this case, included rice (grain), corn (grain), cassava (tuber), and tea leaves.

$\mathrm{DIR}=\Sigma\left(\mathrm{C}_{\text {food }} \times \mathrm{IR}_{\text {food }} / \mathrm{BW}\right)$ where $\mathrm{C}_{\text {food }}$ is the concentration of a particular PTE in food (rice, corn, cassava, tea leaves) $\left(\mathrm{mg} \mathrm{kg}^{-1}\right)$, IR is the ingestion rate $\left(\mathrm{g}_{\text {person }}{ }^{-1} \mathrm{day}^{-1}\right.$ ) in food and BW is body weight (70 kg for adults) (USEPA, 2011). Table 2 presents the IR values used to calculate the DIR for an adult and corresponds to: the IR value of Panama as reported in a consultancy by the FAO (Kennedy et al., 2021) for rice; the minimum value for America (García-Casal et al., 2018) for corn considering that Panama consumes corn-based products to a lesser extent than the rest of Central America; the values reported in Nigeria (Afolami et al., 2020) for cassava; an average value reported for Pakistan (commercial black tea brands) (Idrees et al., 2020), and China (tea leaves)(Zhang et al., 2018). Here "teas" are taken to correspond to the herbs used locally for infusions (Ayapana stenolepis and Declieuxia fruticosa).

The ADD was calculated as the sum of the consumed food (Gruszecka-Kosowska, 2019; USEPA, 1989):

$$
\begin{aligned}
\mathrm{ADD}= & \Sigma\left(\mathrm{C}_{\text {food }} \times \mathrm{IR}_{\text {food }} \times \mathrm{EF} \times \mathrm{ED} \times 10^{-3}\right) / \\
& \mathrm{AT} \times \mathrm{BW}
\end{aligned}
$$

where $\mathrm{C}_{\text {food }}$ is the PTE concentration in the investigated food $\left(\mathrm{mg} \mathrm{kg}^{-1}\right), \mathrm{IR}_{\text {food }}$ is the intake rate of cereals (g person ${ }^{-1}$ day $^{-1}$ ), EF is exposure frequency: $365 \mathrm{~d} \mathrm{y}^{-1}$, ED is exposure duration with $30 \mathrm{y}$ for adults (USEPA, 2011), AT is the average time in days with $\mathrm{ED} \times 365$ for non-carcinogens, and $70 \mathrm{y} \times 365$ for carcinogens (Gruszecka-Kosowska, 2019; USEPA, 2001), BW is body weight (70 kg) and $10^{-3}$ is a unit conversion factor.

The non-carcinogenic risk represents the risk of daily exposure to PTEs (Gruszecka-Kosowska, 2019). The HQ is the non CR, where a value of 1 refers to the threshold reference value as suggested by the US Environmental Protection Agency (Pan et al., 2019), and is calculated as follows (USEPA, 1989):
Table 2 The IR values for different types of edible

\begin{tabular}{|c|c|c|}
\hline Type of plant & IR $\left(\mathrm{g}\right.$ person ${ }^{-1}$ day $\left.^{-1}\right)$ & Reference \\
\hline Rice, grain & 125.2 & Kennedy et al., (2021) \\
\hline Corn, grain & 50.0 & García-Casal et al., (2018) \\
\hline Cassava, tuber & 42.0 & Afolami et al., (2020) \\
\hline Tea leaves & 10.9 & Idrees et al., (2020)/ Zhang et al., (2018) \\
\hline
\end{tabular}
plants 
Table 3 The RfD value of the non-carcinogenic elements and the SF for carcinogenic elements

\begin{tabular}{lll}
\hline Element & $\mathrm{RfD}\left(\mathrm{mg} \mathrm{kg}^{-1} \mathrm{~d}^{-1}\right)$ & $\mathrm{SF}\left(\mathrm{mg} \mathrm{kg}^{-1} \mathrm{~d}^{-1}\right)$ \\
\hline $\mathrm{Cu}$ & $4.0 \times 10^{-2}$ & 1.7 \\
$\mathrm{Zn}$ & $3.0 \times 10^{-1}$ & \\
$\mathrm{As}$ & $3.0 \times 10^{-4}$ & 1.5 \\
$\mathrm{Sb}$ & $4.0 \times 10^{-4}$ & \\
$\mathrm{Ba}$ & $2.0 \times 10^{-1}$ & \\
$\mathrm{Hg}$ & $3.0 \times 10^{-4}$ & \\
\hline
\end{tabular}

$\mathrm{HQ}=\mathrm{ADD} / \mathrm{RfD}$

where $\mathrm{HQ}$ is the hazard quotient and RfD is the reference dose for a particular PTE. The RfD values for the PTEs (USEPA, 2019) in this study are presented in Table 3. The total non CR (HQt) value for the investigated PTEs was calculated as so (USEPA, 1989)

$\mathrm{HQt}=\mathrm{HQ}_{1}+\mathrm{HQ}_{2}+\cdots+\mathrm{HQ}_{\mathrm{n}}$

where HQ are the hazard quotient values for the 1-n PTEs herein investigated.

The CR values of the PTEs from dietary exposure were calculated by the formula (GruszeckaKosowska, 2019; USEPA, 1989):

$\mathrm{CR}=\mathrm{ADD} \times \mathrm{SF}$

where CR is carcinogenic risk and SF is the oral slope factor over a lifetime for a particular PTE. The SF plays a key role being that the daily toxin intake results in an incremental risk of an individual developing cancer (Pan et al., 2019). Table 3 presents the SF values for the carcinogenic elements (Pan et al., 2019) in this study. The total CR value appears as the sum of the partial CR values (USEPA, 1989).

$\mathrm{CRt}=\mathrm{CR}_{1}+\mathrm{CR}_{2}+\cdots+\mathrm{CR}_{\mathrm{n}}$

where CR are the carcinogenic risk values for the 1-n PTEs herein investigated.

\section{Statistical analyses}

Microsoft Excel spreadsheets were used to manage the results. Minitab 15 was employed to analyse the statistical parameters of the analytical results.

\section{Results}

PTEs and BAC

The synthetic statistical parameters for the group of samples are provided in Table 4 and SF1, all the obtained results for plants are expressed in ST2. The $\mathrm{Cu}$ concentrations in plant leaves varied between 4.3 and $57.3 \mathrm{mg} \mathrm{kg}^{-1}$, while the BAC values indicated that $\mathrm{Cu}$ absorption was a weak to strong absorption accumulation in plants. It was remarkable that Xylopia frutescens Aubl was the species with the highest accumulation. The $\mathrm{Zn}$ concentrations in plant leaves were between 5.7 and $273.1 \mathrm{mg} \mathrm{kg}^{-1}$, while the BAC values indicated that $\mathrm{Zn}$ absorption went from weak to strong absorption accumulation in plants. In this case, Araceae morphospecies was the plant taxon with the most accumulation. The As concentrations in plant leaves were between $<0.1$ and $54.5 \mathrm{mg} \mathrm{kg}^{-1}$, while the BAC values indicated very weak to strong absorption accumulation. The taxon with the most accumulation was Poaceae morphospecies. The $\mathrm{Sb}$ concentrations in plant leaves were between $<1.0$ and $9.7 \mathrm{mg} \mathrm{kg}^{-1}$, while the BAC values denoted a weak absorption to strong accumulation, with Declieuxia fruticosa (Willd) Kuntze being the species with the most accumulation. The Ba concentrations in plant leaves went from $<5.0$ to $319.9 \mathrm{mg} \mathrm{kg}^{-1}$, and BACs indicated very weak to moderate absorption. The $\mathrm{Hg}$ concentrations in leaves were between $<0.1$ and $191.2 \mathrm{ng} \mathrm{g}^{-1}$, while the BAC values indicated a very weak absorption to strong accumulation, with Anacardium excelsum (Bertero \& Balb. ex Kunth) Skeels being the taxon with the highest accumulation rate for these elements. All the plants herein indicated with maximum concentrations corresponded to non-edible plants.

Table 5 is a compendium of the $\mathrm{Cu}, \mathrm{Zn}, \mathrm{As}, \mathrm{Sb}, \mathrm{Ba}$, and $\mathrm{Cu}$ concentrations in plants from different countries around the world in both uncontaminated and contaminated areas to compare these values to those obtained at the Remance gold mine for edible products like rice (grain), corn (grain), cassava (tuber), tea leaves (medicinal plants), grass (leaves), and plants in general (leaves).

For rice, the average $\mathrm{Cu}$ concentration value at Remance ( $5.2 \mathrm{mg} \mathrm{kg}^{-1}$ ) was slightly higher than that reported by Kabata-Pendias (2011) for contaminated sites $\left(4.0 \mathrm{mg} \mathrm{kg}^{-1}\right)$, while the As contents 


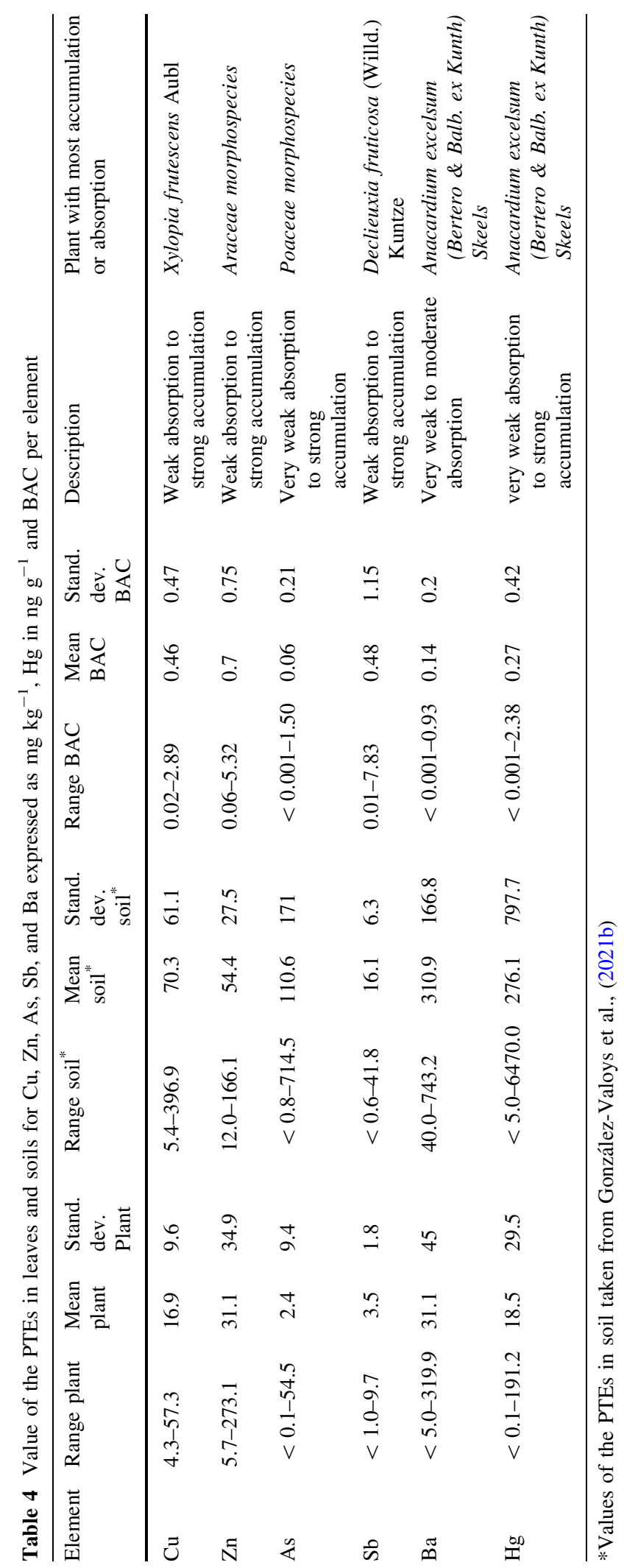


Table 5 Comparative table of the uncontaminated and contaminated sites in several countries for rice, corn, cassava, tea leaves, grass, and plants in general; in relation to the concentration of potentially toxic elements $\left(\mathrm{Cu}, \mathrm{Zn}, \mathrm{As}, \mathrm{Sb}, \mathrm{Ba}, \mathrm{and} \mathrm{Hg}\right.$ in mg kg $\left.{ }^{-1}\right)$

\begin{tabular}{|c|c|c|c|c|c|c|c|c|}
\hline Plant & Site & $\mathrm{Cu}$ & $\mathrm{Zn}$ & As & $\mathrm{Sb}$ & $\mathrm{Ba}$ & $\mathrm{Hg}$ & Reference \\
\hline \multirow[t]{6}{*}{ Rice, grains } & $\begin{array}{l}\text { Uncontaminated sites- } \\
\text { different countries }\end{array}$ & & 18.0 & $<0.1$ & & & & Kabata-Pendias, 2011 \\
\hline & Agricultural soils-China & 2.7 & 18.0 & & & & 0.004 & Rothenberg et al., 2011 \\
\hline & Agricultural soils-Italy & 4.8 & 24.6 & $<0.1$ & 1.1 & 9.3 & & $\begin{array}{l}\text { Nadimi-Goki et al., } \\
2014\end{array}$ \\
\hline & Agricultural soils-Sri Lanka & 2.2 & 15.5 & 0.1 & & & & Rajatheja et al., 2021 \\
\hline & $\begin{array}{l}\text { Contaminated site-different } \\
\text { countries }\end{array}$ & 4.0 & & 1.2 & & & 4.900 & Kabata-Pendias, 2011 \\
\hline & $\begin{array}{l}\text { Remance mining area- } \\
\text { Panama }\end{array}$ & 5.2 & 17.9 & 0.2 & 4.4 & 12.1 & $<0.001$ & This work \\
\hline \multirow[t]{8}{*}{ Corn, grains } & $\begin{array}{l}\text { Uncontaminated sites- } \\
\text { different countries }\end{array}$ & & 30.5 & 1.8 & $<2.0$ & & 0.037 & Kabata-Pendias, 2011 \\
\hline & Agricultural soils-Brazil & 1.7 & 17.5 & $<0.1$ & & 2.7 & $<0.030$ & Yada et al., 2020 \\
\hline & Agricultural soils-Poland & 0.5 & 7.4 & $<0.1$ & $<0.1$ & & 0.002 & $\begin{array}{l}\text { Gruszecka-Kosowska, } \\
2020\end{array}$ \\
\hline & $\begin{array}{l}\text { Agricultural soils-Czech } \\
\text { Republic }\end{array}$ & 1.4 & 6.5 & & & & & Adaev et al, 2021 \\
\hline & Industrial area-Greece & 2.3 & 16.0 & 0.2 & 0.4 & & & Antoniadis et al., 2019 \\
\hline & $\begin{array}{l}\text { Coal mining-contaminated } \\
\text { soil-China }\end{array}$ & 1.7 & 22.7 & & & 6.1 & & Hussain et al., 2019 \\
\hline & $\begin{array}{l}\text { Contaminated site-different } \\
\text { countries }\end{array}$ & & & & & & 0.105 & Kabata-Pendias, 2011 \\
\hline & $\begin{array}{l}\text { Remance mining area- } \\
\text { Panama }\end{array}$ & 4.3 & 22.0 & 0.2 & 4.7 & 11.7 & $<0.001$ & This work \\
\hline \multirow[t]{3}{*}{ Cassava, tuber } & Agricultural soils-Ghana & & 7.4 & & & & & Danso et al., 2001 \\
\hline & Agricultural soils-Nigeria & 11.2 & $<0.1$ & & & & & Adejumo et al., 2019 \\
\hline & $\begin{array}{l}\text { Remance mining area- } \\
\text { Panama }\end{array}$ & 7.5 & 9.0 & $<0.1$ & 4.1 & 18.5 & $<0.001$ & This work \\
\hline \multirow[t]{3}{*}{ Tea, leaves } & $\begin{array}{l}\text { Uncontaminated sites- } \\
\text { different countries }\end{array}$ & 20.0 & & & & & 0.040 & Kabata-Pendias, 2011 \\
\hline & Black tea-Pakistan & 8.9 & 1.4 & & & & & Idrees et al., 2020 \\
\hline & $\begin{array}{l}\text { Remance mining area- } \\
\text { Panama }\end{array}$ & 19.2 & 88.8 & 0.6 & 4.7 & 35.5 & 0.002 & This work \\
\hline \multirow[t]{6}{*}{ Grass, leaves } & $\begin{array}{l}\text { Uncontaminated sites- } \\
\text { different countries }\end{array}$ & 6.0 & 31.5 & 2.8 & & & & Kabata-Pendias, 2011 \\
\hline & Uncontaminated sites-Russia & 14.6 & 47.4 & $<0.1$ & & & & $\begin{array}{l}\text { Shtangeeva et al., } \\
\text { 2020a, 2020b }\end{array}$ \\
\hline & Uncontaminated sites-Russia & 12.6 & 37.0 & 0.2 & 0.1 & 7.3 & & $\begin{array}{l}\text { Shtangeeva et al., } \\
\text { 2020a, 2020b }\end{array}$ \\
\hline & $\begin{array}{l}\text { Contaminated sites-different } \\
\text { countries }\end{array}$ & 42.0 & & 31.2 & & & & Kabata-Pendias, 2011 \\
\hline & $\begin{array}{l}\text { Coal mining-contaminated } \\
\text { soil-China }\end{array}$ & 18.5 & 86.4 & & & 41.4 & & Hussain et al., 2019 \\
\hline & $\begin{array}{l}\text { Remance mining area- } \\
\text { Panama }\end{array}$ & 18.3 & 27.3 & 5.5 & 3.0 & 13.7 & 0.019 & This work \\
\hline
\end{tabular}


Table 5 continued

\begin{tabular}{|c|c|c|c|c|c|c|c|c|}
\hline Plant & Site & $\mathrm{Cu}$ & $\mathrm{Zn}$ & As & $\mathrm{Sb}$ & $\mathrm{Ba}$ & $\mathrm{Hg}$ & Reference \\
\hline \multirow[t]{6}{*}{$\begin{array}{l}\text { Different types of } \\
\text { plant leaves }\end{array}$} & $\begin{array}{l}\text { Uncontaminated sites- } \\
\text { different countries }\end{array}$ & & & & & 7.5 & & Kabata-Pendias, 2011 \\
\hline & Uncontaminated sites-Russia & 15.0 & 34.2 & 0.1 & & & & $\begin{array}{l}\text { Shtangeeva et al., } \\
\text { 2020a, 2020b }\end{array}$ \\
\hline & Uncontaminated sites-Russia & 9.2 & 50.0 & 0.2 & 0.1 & 19.0 & & $\begin{array}{l}\text { Shtangeeva et al., } \\
2020 \mathrm{a}, 2020 \mathrm{~b}\end{array}$ \\
\hline & $\begin{array}{l}\text { Coal mining-contaminated } \\
\text { soil-China }\end{array}$ & 7.1 & 43.1 & & & 25.4 & & Hussain et al., 2019 \\
\hline & Gold mining-Ethiopia & 36.9 & 96.0 & 8.8 & 0.3 & & & $\begin{array}{l}\text { Getaneh \& Alemayehu, } \\
2006\end{array}$ \\
\hline & $\begin{array}{l}\text { Remance mining area- } \\
\text { Panama }\end{array}$ & 16.9 & 31.1 & 3.4 & 3.9 & 36.5 & 0.021 & This work \\
\hline
\end{tabular}

$\left(0.2 \mathrm{mg} \mathrm{kg}^{-1}\right)$ were higher than the value for uncontaminated sites $\left(0.005 \mathrm{mg} \mathrm{kg}^{-1}\right)$ but lower than the reference level for contaminated sites $\left(1.2 \mathrm{mg} \mathrm{kg}^{-1}\right)$ (Kabata-Pendias, 2011). The concentrations of $\mathrm{Sb}$ (4.4 $\mathrm{mg} \mathrm{kg}^{-1}$ ) and $\mathrm{Ba}\left(12.1 \mathrm{mg} \mathrm{kg}^{-1}\right)$ were higher than those reported in agricultural soils in Italy (1.1 $\mathrm{mg} \mathrm{kg}^{-1}, 9.3 \mathrm{mg} \mathrm{kg}^{-1}$, respectively) (NadimiGoki et al., 2014). The average value of the $\mathrm{Zn}$ concentrations $\left(17.9 \mathrm{mg} \mathrm{kg}^{-1}\right.$ ) was similar to the values reported for uncontaminated sites (18.0 mg kg-1) (Kabata-Pendias, 2011) and in agricultural areas (15.5-24.6 mg kg ${ }^{-1}$ ) (Nadimi-Goki et al., 2014; Rajatheja et al., 2021; Rothenberg et al., 2011). Finally, the $\mathrm{Hg}$ concentrations were lower than the detection limit $\left(<0.001 \mathrm{mg} \mathrm{kg}^{-1}\right)$.

For corn, $\mathrm{Cu}, \mathrm{Zn}, \mathrm{As}, \mathrm{Sb}$, and Ba were higher than in agricultural soils (Adaev et al., 2021; GruszeckaKosowska, 2020), while Zn was higher than cassava in agricultural soils (Danso et al., 2001). In tea leaves, the average $\mathrm{Cu}$ concentration fell within the same range as in uncontaminated areas (Kabata-Pendias, 2011), and $\mathrm{Zn}$ concentrations were much higher than those reported for commercial tea by Idrees et al (2020). In grass and plants, $\mathrm{Cu}, \mathrm{As}, \mathrm{Sb}$, and $\mathrm{Ba}$ were higher than in the uncontaminated sites reported by Shtangeeva et al., (2020a, b).

\section{Statistical analysis}

Figure 2 presents the dendrogram for the PTEs studied in Remance plant leaves and ST3 presents Pearson's correlation. Pearson's correlation showed that $\mathrm{Cu}$ was significantly related to $\mathrm{Zn}$, meanwhile, As was related both to $\mathrm{Ba}$ and $\mathrm{Hg}$, and $\mathrm{Ba}$ appears to be related to $\mathrm{Hg}$. After a multivariate analysis, the relation among these six PTEs is displayed in the dendrogram of Fig. 2. This statistical approach clearly separated PTEs into two subgroups: one with $\mathrm{Cu}$ and $\mathrm{Zn}$, and another including $\mathrm{As}, \mathrm{Hg}, \mathrm{Ba}$, and $\mathrm{Sb}$.

Transfer of PTEs from soils to plants

Figure 3 shows a combined graph of the percentages taken in each step of the BCR sequential extraction for $\mathrm{Cu}$ and As, respectively. The total extracted PTEs are displayed in ST3. It is possible to consider the first three BCR steps $(\mathrm{S} 1+\mathrm{S} 2+\mathrm{S} 3)$ to be the fractions, including the potentially labile or reactive species, while the residual fraction can be taken as unavailable for transport, plant uptake, or as bioaccessible to humans (Madrid et al., 2007; Kelepertzis et al., 2013). The first fraction corresponds to the water-soluble fraction, which is easily exchangeable and interpreted as the most mobile and bioavailable for the environment (Pérez-López et al., 2008). Fraction 2 (metals bound to oxides Fe and $\mathrm{Mn}$ ) and fraction 3 (complexed with sulphides and organic matter) can be mobilised under increasing reducing or oxidising conditions, respectively (Kelepertzis et al., 2013). For $\mathrm{Cu}$, fractions 1,2 and 3 averaged $4.45,9.15$ and $4.34 \%$, respectively, with an average total labile fraction of $17.94 \%$ and fraction 2 with the highest contribution (Fig. 3). For As, fractions 1, 2 and 3 averaged 0.04, 0.40 and $1.39 \%$, respectively, with an average total labile fraction of $1.82 \%$ and fraction 3 with the highest contribution (Fig. 3). 


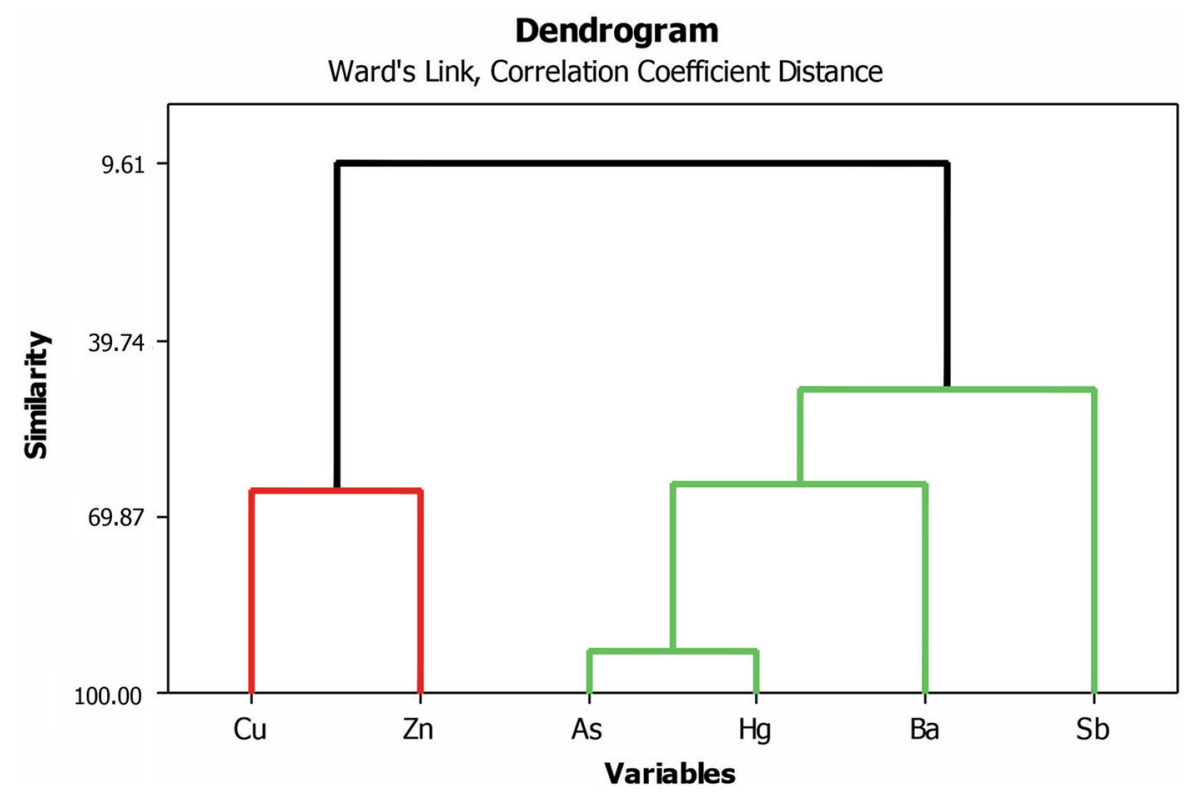

Fig. 2 Dendrogram shows results of cluster analysis (Ward's method) and linkage distance between parameters of the PTEs found in the leaves samples

Table ST4 presents the BAC and BC for a group of samples with high As and $\mathrm{Cu}$ contents in soil. These coefficients were used to evaluate the bioavailability of PTEs, and the plant's capacity to bioaccumulate $\mathrm{Cu}$ and As and to bioconcentrate their available fractions. Figure 4 shows a bar graph to compare the fraction available in soil (obtained by BCR) and the concentration in the leaves of plants for $\mathrm{Cu}$ and $\mathrm{As}$. $\mathrm{Cu}$ is seen as an essential element for plants and appears as being more available in soil (BCR), while plants show good uptake capacity and often high accumulation rates (average BC 3.97). As, which is scarcely available in most soils (mean BC: 0.88), also has lower uptake rates.

Figure 5a shows the correlation detected by Pearson's test between the $\mathrm{Cu}$ concentration in plants and the $\mathrm{Cu}$ fraction available in soil, which is weakly negative. Figure $5 \mathrm{c}$ shows the relation between the As concentration in plants and the As fraction available in soil. No clear correlation is noted, albeit a very weakly positive one, which seems to be dominated by having low As absorption concentrations available in soil. Figures $5 \mathrm{~b}$ and $\mathrm{d}$ show the positive and closer relationship between the $\mathrm{BAC}$ and $\mathrm{BC}$ indices for $\mathrm{Cu}$ and As, respectively.
Human health risk assessment

Daily intake rates

Table 6 shows the DIR values of PTEs for the edible products obtained from the Remance gold mine. The inhabitants' diet is based on products like rice, corn, or cassava, which are produced locally and consumed daily, with tea leaves consumed sporadically as medicinal tea. The DIR values of each edible product are compared to the provisional maximum tolerable daily intakes (PMTDI) (mg kg ${ }^{-1}$ bw day ${ }^{-1}$ ) (Gruszecka-Kosowska, 2020) as so: Cu 0.5 (FAO/WHO, 2001), Zn 1 (FAO/WHO, 2001), As 0.0021 (FAO/ WHO, 1989), Sb 0.006 (WHO, 2008), Ba 0.02 (EU, 2012), Hg 0.0006 (FAO/WHO, 2011). The values of $\mathrm{Cu}$ DIR (2.024 to 9.301), Zn DIR (5.370 to 32.015), Sb DIR (0.716 to 7.780), and Ba DIR (4.562 to 21.642) exceeds the PMTDI in all foods, while As DIR $(0.078$ to 0.268 ) exceeds in food, except for cassava, and the $\mathrm{Hg}$ DIR is only marked in tea leaves $(0.0008$ to 0.0028) and exceeds the PTMDI.

The non-carcinogenic risk of PTEs

The non CR of PTEs was evaluated with the HQ, which was set at 1 (USEPA, 1989). Values exceeding 1 were 

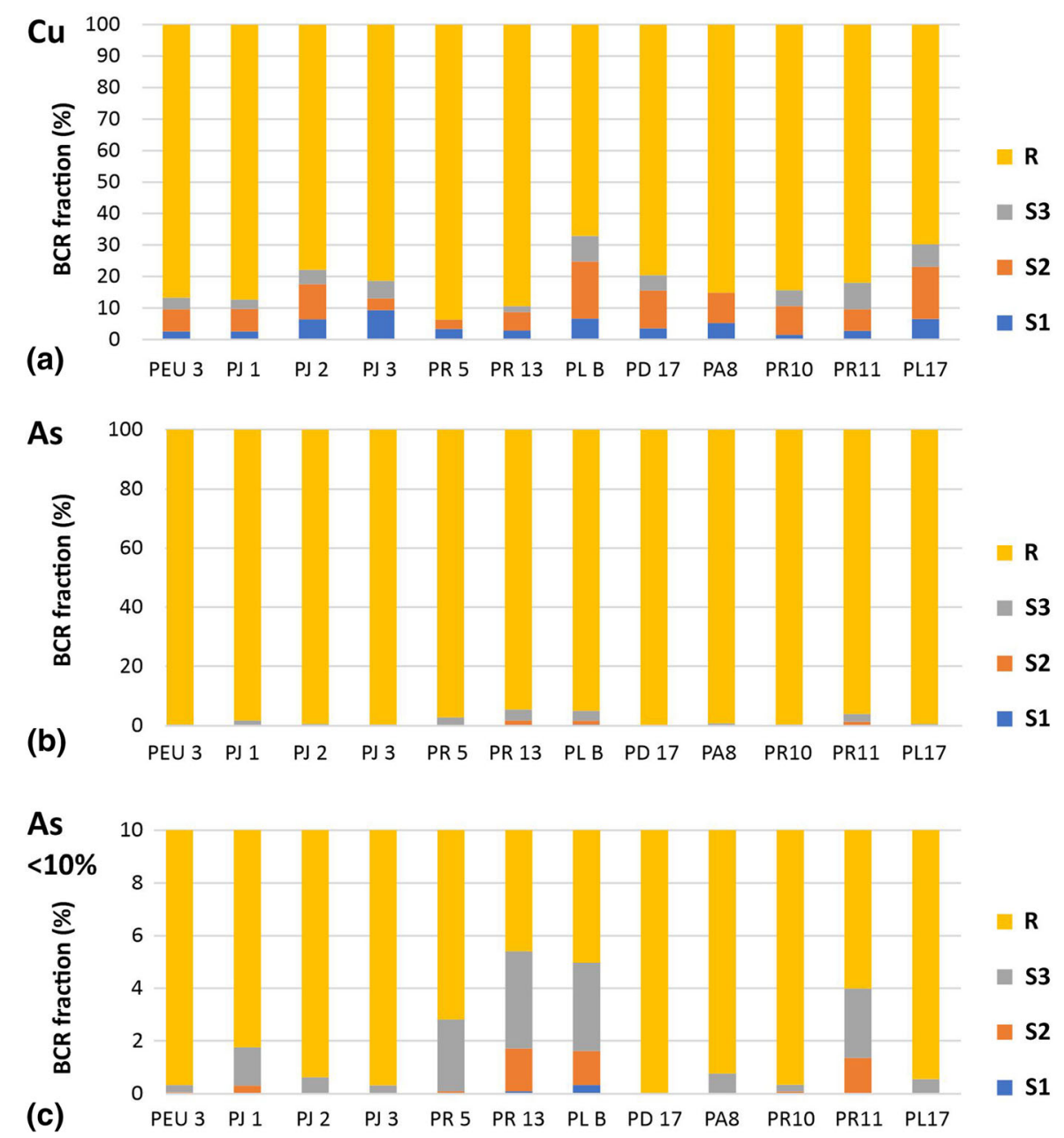

Fig. 3 Combined bar graph for the BCR fractions and the residual in the plant-associated soil samples. a Cu fraction. b As fraction. c Detail of the fraction of As less than $10 \%$
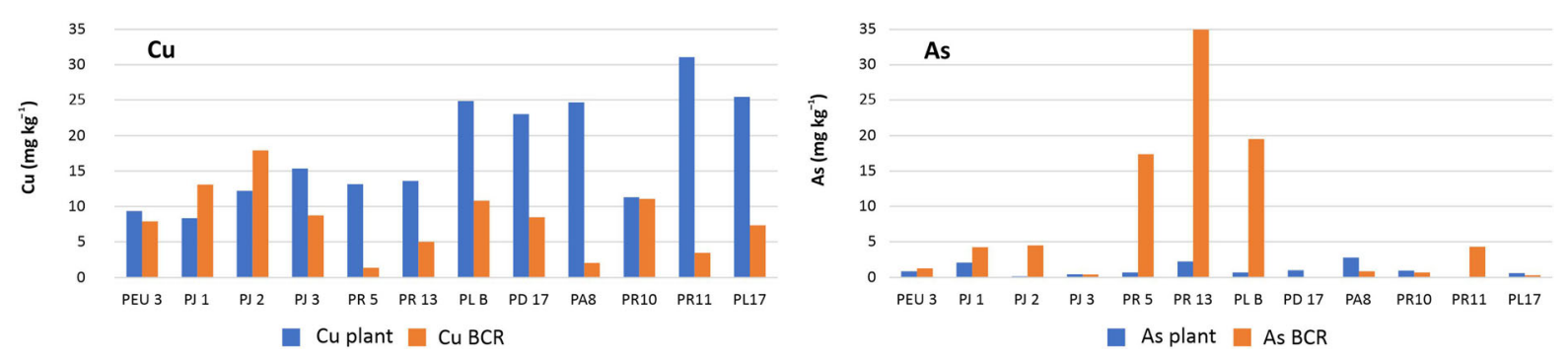

Fig. 4 Bar graph comparing $\mathrm{Cu}$ and As concentration in leaves and available fraction (BCR S1 $+\mathrm{S} 2+\mathrm{S} 3)$

considered a non CR. Figure 6a shows the HQ for the PTEs of the studied edible plant and ST5 values. As we can see, the HQ value was exceeded by $\mathrm{Sb}$ in them all and in this order: rice $>$ corn $>$ cassava $>$ tea leaves $(19.451>18.304>6.075>1.830)$. Cu, Zn, As, Ba, and $\mathrm{Hg}$ did not exceed the value of 1 for HQ. The total HQ value (sum of the HQ for PTEs) of all the edible plants exceeded 1 , which means that it represents a non CR. 

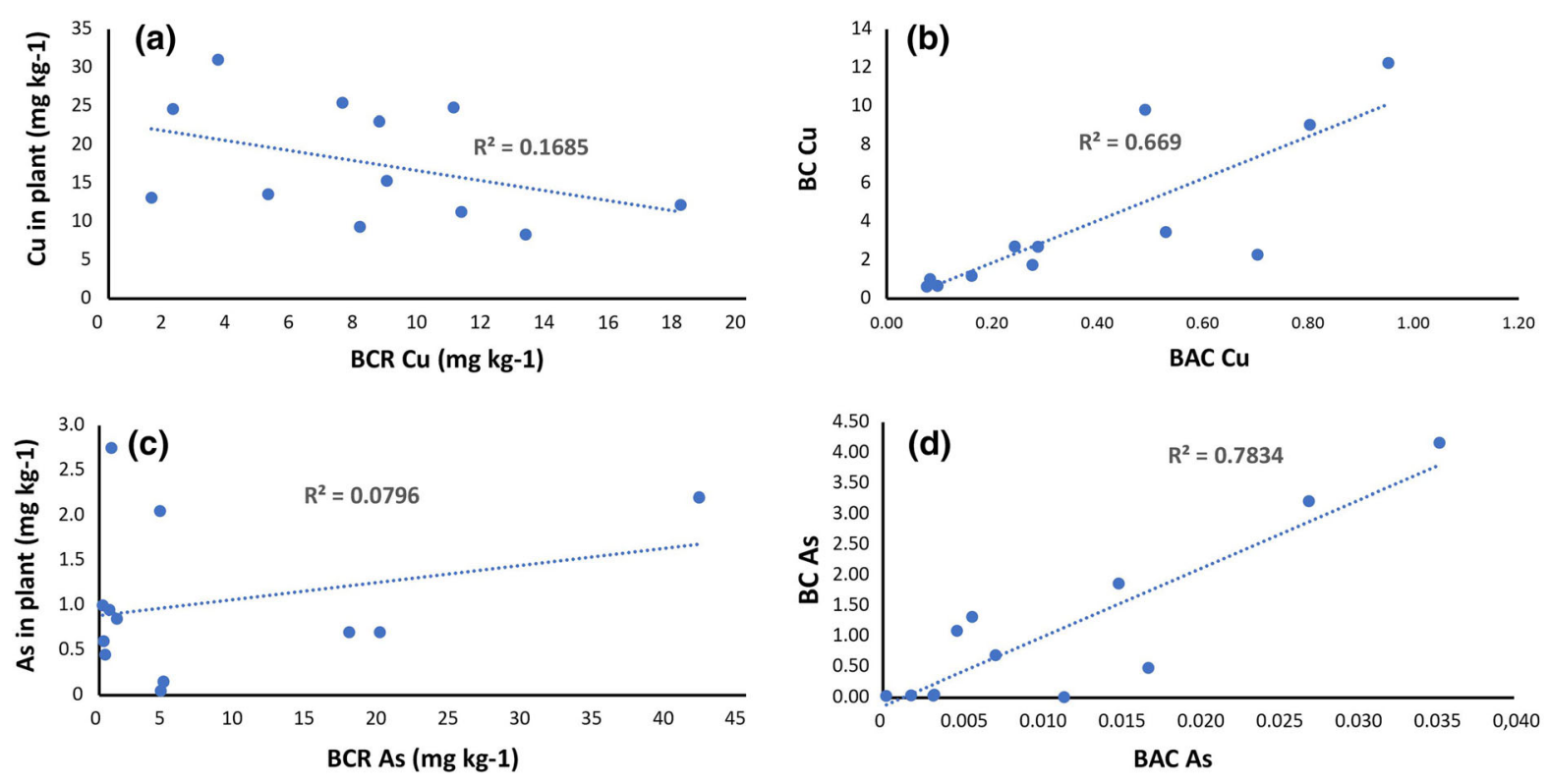

Fig. 5 a Cu concentration in the plant vs available $\mathrm{Cu}$ concentration in soil (BCR). b Bioconcentration and bioaccumulation of $\mathrm{Cu}$ in the plant. $\mathbf{c}$ As concentration in the plant vs available As concentration in soil (BCR). d Bioconcentration and bioaccumulation of As in the plant

Table 6 The DIR ( $\mathrm{mg} \mathrm{kg}^{-1} \mathrm{day}^{-1}$ ), values of PTEs for the food products obtained from the Remance gold mine

\begin{tabular}{llllllrr}
\hline Edible plants & ID & DIR Cu & DIR Zn & DIR As & DIR Sb & DIR Ba & DIR Hg \\
\hline Rice, grain & PR15 & 9.301 & 32.015 & 0.268 & 7.780 & 21.64 & $0.00009^{*}$ \\
Corn, grain & PR16 & 3.036 & 15.679 & 0.107 & 3.321 & 8.36 & $0.00004^{*}$ \\
Cassava, tuber & PR8 & 4.470 & 5.370 & $0.030^{*}$ & 2.430 & 11.10 & $0.00003^{*}$ \\
Tea leaves & PM1 & 2.024 & 8.074 & 0.101 & 0.732 & 4.56 & 0.00078 \\
Tea leaves & PM4 & 3.963 & 19.550 & 0.078 & 0.716 & 6.49 & 0.00280 \\
PMTDI & & 0.500 & 1.000 & 0.002 & 0.006 & 0.02 & 0.00060 \\
\hline
\end{tabular}

PMTDI: provisional maximum tolerable daily intakes $\left(\mathrm{mg} \mathrm{kg}^{-1} \mathrm{day}^{-1}\right)$

*Calculations use the half of the detection limit

\section{The carcinogenic risk of PTEs}

The acceptable CR risk level was set to equal $1 \times 10^{-6}$ for an individual PTE and to equal $1 \times 10^{-4}$ for the sum of carcinogenic PTEs (USEPA, 1989). Values exceeding this are considered a CR. Figure 6b shows the $\mathrm{CR}$ for $\mathrm{Cu}$ and Fig. $6 \mathrm{c}$ for As and the ST5 includes the complete values. The acceptable $\mathrm{CR}$ value is exceeded by As in rice $\left(7.67 \times 10^{-5}\right)$, corn $\left(3.06 \times 10^{-5}\right)$ and tea leaves $\left(2.22 \times 10^{-5}\right.$ to $\left.2.89 \times 10^{-5}\right)$. Excess $\mathrm{Cu}$ was obtained in all the edible plants $\left(5.10 \times 10^{-4}\right.$ to $\left.2.34 \times 10^{-3}\right)$ in this order: rice $>$ cassava $>$ tea leaves $>$ corn. This is the same order for the total CR.

\section{Animal nutrition for ruminants}

In the Remance mining area and its surroundings, peasants perform subsistence livestock work and graze horses. The mean $\mathrm{Cu}$ value in grass (Poaceae morphospecies) was $18.3 \mathrm{mg} \mathrm{kg}^{-1}$ and was $16.9 \mathrm{mg} \mathrm{kg}^{-1}$ in plants in general. These values exceed the maximum authorised for $\mathrm{Cu}\left(10 \mathrm{mg} \mathrm{kg}^{-1}\right)$ for complete feed requirements in animal nutrition for ruminants (e.g., cattle, cows, and horses) of the 
(a) 25.000

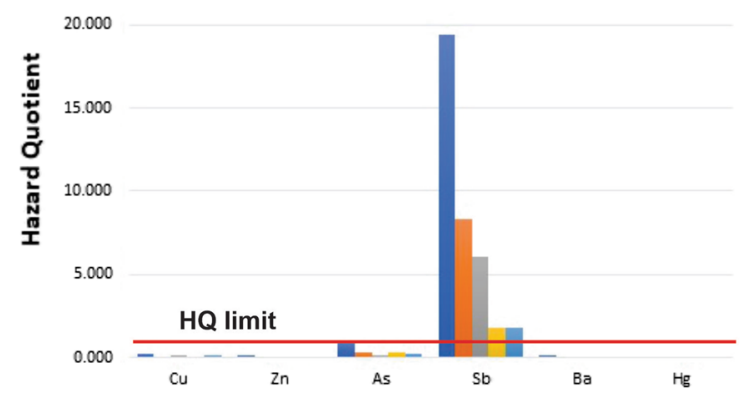

Eice, grain PR15

ncorn, grain PR16

= Cassara, tuber PR8

- Tea leaves PM1

- Tea leaves PM4 (b) $2.50 \mathrm{E}-03$

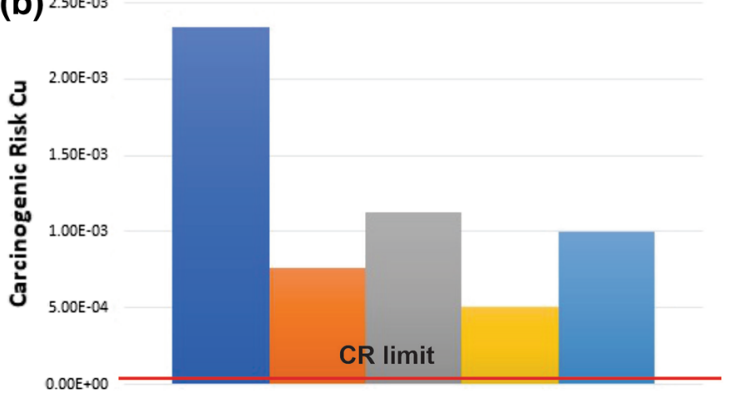

(c) $9.00 \mathrm{E}-05$

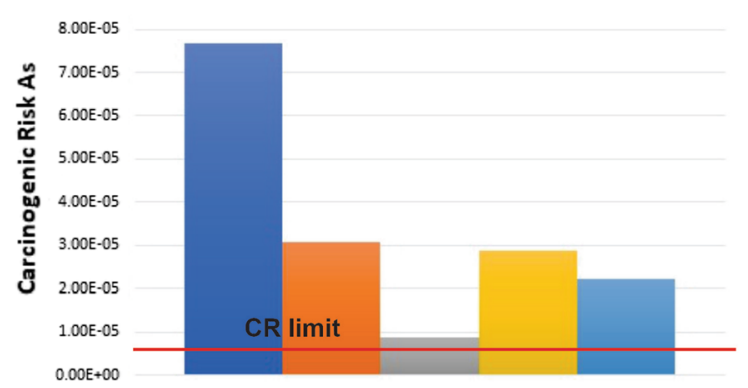

Fig. 6 a Bar chart for non-carcinogenic (HQ) risk for PTEs in edible plants from the Remance gold mine. b Carcinogenic risk for Cu in edible plants studied for the Remance gold mine. c Carcinogenic risk for As in edible plants studied for the Remance gold mine

National Research Council, USA (Aquilina et al., 2016; López-Alonso \& Miranda, 2020; NRC, 2001). The mean $\mathrm{Zn}$ value in grass was $27.3 \mathrm{mg} \mathrm{kg}^{-1}$, and $31.1 \mathrm{mg} \mathrm{kg}^{-1}$ in plants in general. Both these values exceed the estimated value of the daily diet requirement for cattle for $\mathrm{Zn}\left(22.8 \mathrm{mg} \mathrm{kg}^{-1}\right.$ ) (NRC, 2001). For $\mathrm{As}, \mathrm{Ba}, \mathrm{Sb}$, and $\mathrm{Hg}$, the National Research Council of the USA does not establish an estimated value for the daily diet requirements of cattle.

\section{Discussion}

Given that the soils and plants in the surroundings of the abandoned Remance gold mine present high concentrations of PTEs, such as $\mathrm{Cu}, \mathrm{Zn}, \mathrm{As}, \mathrm{Sb}, \mathrm{Ba}$, and $\mathrm{Hg}$, associated with mineralisation (Nelson \& Ganoza, 1999), it is essential to identify the degree to which plants, and especially the crops grown by farmers like rice, corn, cassava, among others, are affected (Ministerio de Ambiente Panamá, 2012). It is also necessary to identify the risks for livestock and as collateral risks for human health. The mean concentration of the PTEs in the leaves of a diversity of studied plants comes in this order, $\mathrm{Zn}=\mathrm{Ba}>\mathrm{Cu}>$ $\mathrm{Sb}>\mathrm{As}>\mathrm{Hg}$, while $\mathrm{BAC}$ is related to the total amount of PTEs present in soil, and the degree to which a plant absorbs them comes in this order, $\mathrm{Zn}>\mathrm{Sb}>\mathrm{Cu}>\mathrm{Hg}>\mathrm{Ba}>$ As. All this indicates that essential trace elements like $\mathrm{Zn}$ and $\mathrm{Cu}$ (Arif et al., 2016) are absorbed by plants and accumulate more than non-essential elements (Bravo et al., 2015) like $\mathrm{Hg}, \mathrm{Ba}$, and As.

The exception can be $\mathrm{Sb}$, which being non-essential, has been strongly absorbed and accumulated by plants (Mykolenko et al., 2018), even as As, which is in larger total concentrations in soil, evidencing the availability of these PTEs, which was corroborated with the BCR extraction (where the labile or available fractures are extracted for transport and plants) (Madrid et al., 2007; Kelepertzis et al., 2013) for As and $\mathrm{Cu}$, where $\mathrm{Cu}$ was much more available than As.

For the soil-plant transfer of PTEs, a weakly negative linear regression between the $\mathrm{Cu}$ concentrations in plants versus the available $\mathrm{Cu}$ fraction in soil (BCR) was found. Although $\mathrm{Cu}$ is an essential element for plants, it is toxic for them if it appears in soil in large quantities (Adrees et al., 2015; Kumar et al., 
2021; Rather et al., 2020; Shabbir et al., 2020). The relation between bioavailability indices BAC and BC (Kelepertzis et al., 2013) was positive, which reveals that plants' ability to bioaccumulate $\mathrm{Cu}$ is enhanced, as does its ability to bioconcentrate it when $\mathrm{Cu}$ is available in soil.

The scenario is different for As because the relation between the elements in plants and in soil is not as clear. Although this relation was very weakly positive, it seemed to be dominated by having low absorbed As concentrations available in soil. This is a general rule, except for Schefflera morototoni, which absorbs As more efficiently by having mechanisms to tolerate and accumulate this toxic element. One remarkable fact is that, although As is more available in soil, plants do not always absorb it more, mainly because it is not an essential element (Ackova, 2018) and can be more related to each plant species' capacity to exclude or tolerate this PTE (Chamba et al., 2017; Dixit et al., 2015). The relation between bioavailability indices $\mathrm{BAC}$ and $\mathrm{BC}$ was positive, which indicates that a plant's ability to bioaccumulate As increases, as does its ability to bioconcentrate As when it is available in soil.

The mean concentration of both $\mathrm{Cu}$ and $\mathrm{Zn}$ in the leaves of the plants around the Remance gold mine, compared to plants from other parts of the world, fell within the ranges known for between uncontaminated (Shtangeeva et al., 2020a, 2020b) and contaminated zones (Hussain et al., 2019), while the As, Sb and Ba values were similar to those reported from contaminated areas (Getaneh \& Alemayehu, 2006; Hussain et al., 2019). More specifically, the $\mathrm{Cu}$ concentrations in grass were similar to those from contaminated areas (Hussain et al., 2019), while As, Sb and Ba obtained higher values than those reported in uncontaminated areas (Shtangeeva et al., 2020a, 2020b), and the Zn concentrations were similar to those from uncontaminated areas (Kabata-Pendias, 2011). All these values imply harmful effects on the health of the cattle grazing in the study area for these PTEs because they are higher than those recommended for the animal nutrition of ruminants (Johnsen \& Aaneby, 2019), as is the case of $\mathrm{Cu}$ and $\mathrm{Zn}$ (NRC, 2001). However, there are no estimated requirements set for cattle according to the National Research Council, USA, for the other PTEs (As, Sb, Ba, and $\mathrm{Hg}$ ).

The human health risk posed by eating edible plants grown in areas with PTEs can be evaluated with the
PMTDI (Gruszecka-Kosowska, 2020). This value was exceeded for $\mathrm{Cu}, \mathrm{Zn}, \mathrm{Sb}$ and $\mathrm{Ba}$ in all the studied edible plants (rice, corn, cassava, tea leaves), and for As in rice, corn and tea leaves, and for $\mathrm{Hg}$ only in tea leaves. Although some of these elements can be considered essential for plants or humans, they can be toxic to human health if consumed in excess, such as $\mathrm{Cu}$, which brings about abnormalities in the nervous system, liver and kidneys, and even death, or $\mathrm{Zn}$, which reduces the immune function and HDL cholesterol, and also causes fever. Non-essential PTEs can cause cirrhosis, cancer of the skin, liver and lungs, or embryo theratogenesis (As), respiratory system damage $(\mathrm{Sb})$, gastroentheritis, muscle paralysis, ventricular fibrillation and extrasystoles $(\mathrm{Ba})$, neurological damage (mercurialism), asthenic-vegetative syndrome or Minamata disease, kidney damage, toxicity to foetus and teratogenic embryo $(\mathrm{Hg})$ (Bini \& Wahsha, 2014).

The HQ values, with which the non-carcinogenic risk of edible plants is evaluated (GruszeckaKosowska, 2020), were exceeded for Sb, which places rice, corn, cassava, and tea leaves at risk levels. The long-term intake of small amounts of $\mathrm{Sb}$ may induce chronic antimony poisoning, while Sb exposure has been shown to induce DNA damage and oxidative stress, and to generate reactive oxygen species (ROS) causing apoptosis. As $\mathrm{Sb}$ geochemical behaviour is similar to that of As, it is likely that DNA damage induced by $\mathrm{Sb}$ follows similar pathways to those for As (Bini \& Wahsha, 2014; Franco et al., 2009).

The acceptable CR was surpassed by all the edible plants for $\mathrm{Cu}$, and also for As in rice, corn and tea leaves, which meant that the total acceptable CR was exceeded by all the studied edible plants and posed a risk for the health of the people who eat them in the studied mining area. One of the most important risks could come through As as long-term exposure can lead to skin lesions, internal cancers, neurological problems, pulmonary disease, peripheral vascular disease, hypertension and cardiovascular disease, and diabetes mellitus (Jaishankar et al., 2014; Smith et al., 2000).

The Remance gold mine is an abandoned mine. When abandoned mines are not properly shut down, they pose an environmental problem that also affects the inhabitants of their surroundings (Kaninga et al., 2020; Khlelifi et al., 2020). Therefore, environmental surveillance programmes need to be set up to avoid harming populations. 


\section{Conclusion}

The flora and crops of the Remance gold mine bioaccumulated the herein studied PTEs in this order: $\mathrm{Zn}>\mathrm{Sb}>\mathrm{Cu}>\mathrm{Hg}>\mathrm{Ba}>$ As. This finding indicates that this area has absorbed mostly essential elements like $\mathrm{Zn}$ and $\mathrm{Cu}$ along with $\mathrm{Sb}$ which is nonessential but has a very high affinity to be absorbed by plants. Of the major elements in soil, such as As and $\mathrm{Cu}, \mathrm{Cu}$ was more available than As. This revealed that plants bioconcentrated $\mathrm{Cu}$ more than As despite As found in a larger total quantity in soil.

The BAC vs. BC relation was positive for both the tested $\mathrm{Cu}$ and As elements, which denotes that plants' ability to bioaccumulate and bioconcentrate is linked with the availability of elements in soil.

The relationship between the $\mathrm{Cu}$ concentration in plants and the amount of $\mathrm{Cu}$ available in soil was weak and not very significant, as is the case for As. What this implies is that the amount of As available in soil was not directly linked with its concentration in plants, and this could, in turn, be linked with the mechanisms that each plant species possesses to absorb and bioaccumulate, or exclude, As.

The average $\mathrm{Cu}$ and $\mathrm{Zn}$ concentrations present in the grass and plants around the Remance gold mine exceeded the recommended requirements for the animal nutrition of ruminants according to the National Research Council, USA. So this could pose some health risks for the livestock grazing in this area.

$\mathrm{Sb}$ was the PTE that posed the main non CR. As and $\mathrm{Cu}$ were the PTEs that represented a CR because they exceeded the acceptable CR limit in the studied edible plants (rice, corn, cassava, tea leaves) that are planted and consumed by peasants as part of their daily diet.

We recommend the study area being bioremediated to reduce the posed risk for the environment and the people inhabiting the area.

Acknowledgements The authors thank the National Secretary of Science and Technology (SENACYT), the Institute for the Training and Use of Human Resources (IFARHU) of Panama, the Technological University of Panama (UTP), the University of Castilla-La Mancha (UCLM), and the Autonoma University of Madrid (UAM) for their research support, and to the National Directorate of Mineral Resources of the Ministry of Commerce and Industry (MICI) of Panama for granting access to the Remance mine. They also thank Mr. Doroteo Concepción and Francisco Hernández for their guidance in the Remance area and their knowledge of local plants. Thanks also go to Marcial González for his collaboration with this work. Thanks to Helen
Warburton (Scientific English) for the revision of the English style of the manuscript.

Author contributions The paper was written by AC. G-V, UJ, RR, TM-D, MV-L, EM.G-N, JME, RJ-B, FJ.G-N, and PH. The conceptualization of the study was done by PH, RJ-B, FJ.G-N, and JME. Plants were collected by AG-V and RR and were identified by botanical biologist UJ. The laboratory analyses were carried out by AG-V and EM.G-N.

Funding Open Access funding provided thanks to the CRUECSIC agreement with Springer Nature. This study was funded by the National Secretary of Science and Technology (SENACYT) and the Institute for the Training and Use of Human Resources (IFARHU) of Panama (270-2019-109) and by Fondos para Grupos de Investigación UCLM (2019-GRIN27011).

\section{Declarations}

Conflict of interest The authors declare no conflict of interest.

Open Access This article is licensed under a Creative Commons Attribution 4.0 International License, which permits use, sharing, adaptation, distribution and reproduction in any medium or format, as long as you give appropriate credit to the original author(s) and the source, provide a link to the Creative Commons licence, and indicate if changes were made. The images or other third party material in this article are included in the article's Creative Commons licence, unless indicated otherwise in a credit line to the material. If material is not included in the article's Creative Commons licence and your intended use is not permitted by statutory regulation or exceeds the permitted use, you will need to obtain permission directly from the copyright holder. To view a copy of this licence, visit http://creativecommons.org/licenses/by/4.0/.

\section{References}

Ackova, D. (2018). Heavy metals and their general toxicity on plants. Plant Science Today, 5(1), 14-18. https://doi.org/ 10.14719/pst.2018.5.1.355

Adaev, N., Amaeva, A., \& Khamzatova, M. (2021). Intensification of corn fertilizer system under irrigation conditions in the Chechen republic. International Conference on World Technological Trends in Agribusiness, IOP Conference Series: Earth and Environmental Science, 624, 012002. https://doi.org/10.1088/1755-1315/624/1/012002

Adejumo, O., Oyelowo, O., \& Adejumo, O. (2019). Elevated iron levels in machine-grinded cassava (Manihot esculenta, Euphorbiaceae) in Iwo, southweast Nigeria as determined by Atomic Absorption Spectrometry. Journal of food studies, ISSN 2166-1073, 2019, Vol. 8, N 1.

Adrees, M., Ali, S., Rizwan, M., Ibrahim, M., Abbas, F., Farid, M., Zia-ur-Rehman, M., Irshad, M., \& Bharwana, S. (2015). The effect of excess copper on growth and physiology of important food crops: A review. Environmental 
Science and Pollution Research, 2015(22), 8148-8162. https://doi.org/10.1007/s11356-015-4496-5

Afolami, I., Mwangi, M., Samuel, F., Boy, E., Iiona, P., Talsma, E., Feskens, E., \& Melse-Boonstra, A. (2020). Daily consumption of pro-vitamin A biofortified (yellow) cassava improves serum retinol concentrations in preschool children in Nigeria: a randomized controlled trial. The American journal of clinical nutrition, 113(1), 221-231. https:// doi.org/10.1093/ajen/nqaa290

Antoniadis, V., Golia, E., Liu, Y., Wang, S., Shaheen, S., \& Rinklebe, J. (2019). Soil and maize contamination by trace elements and associated health risk assessment in the industrial area of Volos, Greece. Environment International, 124(2019), 79-88. https://doi.org/10.1016/j.envint. 2018.12.053

Aquilina, G., Azimonti, G., Bampidis, V., Bastos, M., Bories, G., Chesson, A., Cocconceli, P., Flachowsky, G., Gropp, J., Kolar, B., Kouba, M., Puente, S., Lopez-Alonso, M., Mantovani, A., Mayo, B., Ramos, F., Rychen, G., Saarela, M., Villa, R., ... Wester, P. (2016). Revision of the currently authorised maximum copper content in complete feed, EFSA panel on additives and products or substances used in animal feed (FEEDAP). European Food Safety Authority Journal. https://doi.org/10.2903/j.efsa.2016. 4563

Arif, N., Yadav, V., Singh, S., Singh, S., Ahmad, P., Mishra, R., Sharma, S., Tripathi, D., Dubey, N., \& Chauhan, D. (2016). Influence of high and low levels of plant-beneficial heavy metal ions on plant growth and development. Frontiers in Environmental Sciences, 4, 69. https://doi.org/10.3389/ fenvs.2016.00069

Bini, C., \& Wahsha, M. (2014). Potentially Harmful Elements and Human Health. Book PHEs, environment and human health: Potentially harmful elements in the environment and the impact on human health, Chapter 11. https://doi. org/10.1007/978-94-017-8965-3

Bravo, S., Amorós, J. A., Pérez-De-Los-Reyes, C., García, F. J., Moreno, M. M., Sánchez-Ormeño, M., \& Higueras, P. (2017). Influence of the soil $\mathrm{pH}$ in the uptake and bioaccumulation of heavy metals ( $\mathrm{Fe}, \mathrm{Zn}, \mathrm{Cu}, \mathrm{Pb}$ and $\mathrm{Mn}$ ) and other elements ( $\mathrm{Ca}, \mathrm{K}, \mathrm{Al}, \mathrm{Sr}$ and $\mathrm{Ba})$ in vine leaves, Castilla-La Mancha (Spain). Journal of Geochemical Exploration, 174, 79-83. https://doi.org/10.1016/j.gexplo. 2015.12.012

Chaabani, S., Abdelmalek-Babbou, C., Ahmed, H., Chaabani, A., \& Sebei, A. (2017). Phytoremediation assessment of native plants growing on $\mathrm{Pb}-\mathrm{Zn}$ mine site in Northern Tunisia. Environmental Earth Science, 76, 585. https://doi. org/10.1007/s12665-017-6894-0

Chamba, I., Rosado, D., Kalinhoff, C., Selvaraj, T., SánchezRodríguez, A., \& Gazquez, M. (2017). Erato polymnioides - A novel $\mathrm{Hg}$ hyperaccumulator plant in ecuadorian rainforest acid soils with potential of microbeassociated phytoremediation. Chemosphere, 188, 633-641. https://doi.org/10.1016/j.chemosphere.2017.08. 160

Danso, K., Serfor-Armah, Y., Nyarko, B., Osae, S., \& Osae, E. (2001). Determination of some mineral components of cassava (Manihot esculenta Crantz) using instrumental neutron activations analysis. Journal of Radioanalytical and Nuclear Chemistry, 250(1), 139-142.
Dirección de Hidrometeorología de ETESA (2007). Mapa de Clasificación Climática (según Köppen). Retrieved May 23, 2020 from http://www.hidromet.com.pa/mapas.php.

Dixit, R., Malaviya, D. W., Pandiyan, K., Singh, U., Sahu, A., Shukla, R., Singh, B., Rai, J., Sharma, P., Lade, H., \& Paul, D. (2015). Bioremediation of heavy metals from soil and aquatic environment: An overview of principles and criteria of fundamental processes. Sustainability, 2015(7), 2189-2212. https://doi.org/10.3390/su7022189

EU (2012). Assessment of the Tolerable Daily Intake of Barium. European Commission, Scientific Committee on Health and Environmental Risks (SCHER), ISBN 978-9279-30749-2, pp. 13. https://doi.org/10.2772/49651.

FAO/WHO (1989). Expert Committee on Food Additives, and World Health Organization. Evaluation of Certain Food Additives and Contaminants. In Thirty-Third Report of the Joint FAO/WHO Expert Committee on Food Additives; WHO Technical Report Series, No. 776; Joint FAO/WHO Expert Committee on Food Additives: Geneva, Switzerland, 1989.

FAO/WHO (2001). Expert Committee on Food Additives, and World Health Organization. Food Additives and Contaminants; Codex Alimentarius Commission, Joint FAO/WHO Food Standards Program, ALI-NORM01/12A; Joint FAO/ WHO Expert Committee on Food Additives: The Hague, The Netherlands 2001.

FAO/WHO (2011). Expert Committee on Food Additives, and World Health Organization. Safety Evaluation of Certain Contaminants in Food; Prepared by the Seventy-Second Meeting of the Joint FAO/WHO Expert Committee on Food Additives (JECFA), Mercury (Addendum). Food and Agriculture Organization of the United Nations: Rome, Italy; Joint FAO/WHO Expert Committee on Food Additives: Geneva, Switzerland, 2011.

Franco, R., Sanchez-Olea, R., Reyes-Reyes, E., \& Panayotidis, M. (2009). Environmental toxicity, oxidative stress and apoptosis: menage trois. Mutation Research/Genetic Toxicology and Environmental Mutagenesis, 674(1-2), 3-22. https://doi.org/10.1016/j.mrgentox.2008.11.012

García-Casal, M., Peña-Rosas, J., De-Regil, L., Gwirtz, J., \& Pasricha, S. (2018). Fortification of maize flour with iron for controlling anaemia and iron deficiency in populations (Review). Cochrane Library, Cochrane Database of Systematic Reviews,. https://doi.org/10.1002/14651858. CD010187.pub2

García-Ordiales, E., Higueras, P., Esbrí, J., Roqueñí, N., \& Loredo, J. (2019). Seasonal and spatial distribution of mercury in stream sediments from Almadén mining district. Geochemistry: Exploration, Environment, Analysis, 19(2), 121. https://doi.org/10.1144/geochem2018-029

Getaneh, W., \& Alemayehu, T. (2006). Metal contamination of the environment by placer and primary gold mining in the Adola region of southern Ethiopia. Environmental Geology, 2006(50), 339-352. https://doi.org/10.1007/s00254006-0213-5

Gómez, A. (2008). Contaminación ambiental en áreas asociadas con minas antiguas de oro. Determinación de cianuro en agua y de trazas metálicas en sedimentos, en las quebradas aledañas a las minas Remance y Santa Rosa. Graduation Thesis, Universidad Tecnológica de Panamá, p. 500. 
Gómez-Armesto, A., Carballeira-Díaz, J., Pérez-Domínguez, P., Arias-Estévez, M., Nóvoa-Muñoz, J., Álvarez-Rodríguez, E., Fernández-Sanjurjo, M., \& Núñez-Delgado, A. (2015). Copper content and distribution in vineyards soils from Betanzos (A Coruña, Spain). Spanish Journal of Soil Science. https://doi.org/10.3232/SJSS.2015.V5.N1.06

González-Valoys, A., Arrocha, J., Monteza-Destro, T., VargasLombardo, M., Esbrí, J., García-Ordiales, E., JiménezBallesta, R., García-Navarro, F., \& Higueras, P. (2021a). Environmental challenges related with cyanidation in Central American gold mining, Remance mine (Panama). Journal of Environmental Management under review.

González-Valoys, A., Esbrí, J.M., Campos, J.A., Arrocha, J., García-Noguero E.M., Monteza-Destro, T., Martínez, E., Jiménez-Ballesta, R., Gutiérrez, E., Vargas-Lombardo, M., García-Ordiales, E., García-Giménez, R., García-Navarro, F.J., Higueras, P. (2021b). Ecological and health risk assessments of an abandoned gold mine (Remance, Panama): complex scenarios need a combination of indices. International Journal of Environmental Research and Public Health (2021) under review.

Gruszecka-Kosowska, A. (2019). Human health risk assessment and potentially harmful element contents in the fruits in the Southern Poland. International Journal of Environmental Research and Public Health, 2019(16), 5096. https://doi. org/10.3390/ijerph16245096

Gruszecka-Kosowska, A. (2020). Human health risk assessment and potentially harmful element contents in the cereals cultivated on agricultural soils. International Journal of Environmental Research and Public Health, 2020(17), 1674. https://doi.org/10.3390/ijerph17051674

Higueras, P., Esbrí, J., García-Ordiales, E., González-Corrochano, B., López-Berdonces, M., García-Noguero, E., Alonso-Azcárate, J., \& Martínez-Coronado, A. (2017). Potentially harmful elements in soils and holm-oak trees (Quercus ilex L.) growing in mining sites at the Valle de Alcudia $\mathrm{Pb}-\mathrm{Zn}$ district (Spain)- Some clues on plant metal uptake. Journal of Geochemical Exploration, 182, 166-179. https://doi.org/10.1016/j.gexplo.2016.07.017

Hooda, P. (2010). Assessing Bioavailability of Soil Trace Elements, Chapter 11 Trace Elements in soils. Wiley, Chichester Trace Elements in Soils. John Wiley \& Sons, Ltd 2010, 17:06, 11, pp 229-267. DOI: https://doi.org/10. 1002/9781444319477.ch11.

Hussain, R., Luo, K., Liang, H., \& Hong, X. (2019). Impact of the coal mining-contamination soil on the food safety in Shaanxi. China. Environmental Geochemistry and Health, 2019(41), 1521-1544. https://doi.org/10.1007/s10653018-0233-6

Idrees, M., Jan, F., Hussain, S., \& Salam, A. (2020). Heavy metals level, health risk assessment associated with contamination of Black tea; a case study from Khyber Pakhtunkhwa (KPK), Pakistan. Biological Trace Elements Research, 2020(198), 344-349. https://doi.org/10.1007/ s12011-020-02059-1

Inacio, M., Neves, O., Pereira, V., \& da Silva, E. (2014). Levels of selected potential harmful elements (PHEs) in soils and vegetables used in diet of the population living in the surroundings of the Estarreja Chemical Complex (Portugal). Applied Geochemistry, 2014(44), 38-44.
Jaishankar, M., Tseten, T., Anbalagan, N., Mathew, B., \& Beeregowda, K. (2014). Toxicity, mechanism and health effects of some heavy metals. Interdisciplinary Toxicology, 7(2), 60-72. https://doi.org/10.2478/intox-2014-0009

Johnsen, I., \& Aaneby, J. (2019). Soil intake in ruminants grazing on heavy-metal contaminated shooting ranges. Science of the Total Environment, 687(2019), 41-49. https://doi.org/10.1016/j.scitotenv.2019.06.086

Kabata-Pendias, A. (2011). Trace elements in soil sand plants. CRC Press by Taylor \& Francis Group.

Kamunda, C., Mathuthu, M., \& Madhuku, M. (2016). Health risk assessment of heavy metals in soils from witwatersrand gold mining basin, South Africa. International Journal of Environmental Research and Public Health, 13, 663. https://doi.org/10.3390/ijerph13070663

Kaninga, B., Chishala, B., Maseka, K., Sakala, G., Lark, M., Tye, A., \& Watts, M. (2020). Review: mine tailings in an African tropical environment-mechanisms for the bioavailability of heavy metals in soils. Environmental Geochemistry and Health, 42, 1069-1094. https://doi.org/ 10.1007/s10653-019-00326-2

Kelepertzis, E., \& Stathopoulou, E. (2013). Availability of geogenic heavy metals in soils of Thiva town (central Greece). Environmental Monitoring and Assessment, 2013(185), 9603-9618. https://doi.org/10.1007/s10661013-3277-1

Kennedy, G., Burlingame, B., \& Nguyen, V. (2021). Nutritional contribution of rice and impact of biotechnology and biodiversity in rice-consuming countries. Consultancy for FAO, Retrieved April 13, 2021 from, http://www.fao.org/ 3/Y4751E/y4751e05.htm.

Kumar, V., Pandita, S., Sidhu, G. S., Sharma, A., Khanna, K., Kaur, P., Bali, A., \& Setia, R. (2021). Copper bioavailability, uptake, toxicity and tolerance in plants: A comprehensive review. Chemosphere, 2021(262), 127810. https://doi.org/10.1016/j.chemosphere.2020.127810

Khelifi, F., Melki, A., Hamed, Y., Adamo, P., \& Caporale, A. (2020). Environmental and human health risk assessment of potentially toxic elements in soil, sediments, and oreprocessing wastes from a mining area of southwestern Tunisia. Environmental Geochemistry and Health, 2020(42), 4125-4139. https://doi.org/10.1007/s10653019-00434-Z

López-Alonso, M., \& Miranda, M. (2020). Copper supplementation, A challenge in cattle. Animals, 2020(10), 1890. https://doi.org/10.3390/ani10101890

Madrid, F., Reinoso, R., Florido, M., Díaz, E., Ajmone-Marsan, F., Davidson, C., \& Madrid, L. (2007). Estimating the extractability of potentially toxic metals in urban soils: A comparison of several extracting solutions. Environmental Pollution, 147, 713-722. https://doi.org/10.1016/j.envpol. 2006.09.005

Marguí, E., Hidalgo, M., Queral, I., \& Rodríguez, R. (2006). Métodos de evaluación del riesgo ambiental de los residuos minero-metalúrgicos sólidos. Instituto Geológico y Minero de España, Madrid, 2006, ISBN 84-7840-656-5, pp 395-417.

Melaku, S., Dams, R., \& Moens, L. (2005). Determination of trace elements in agricultural soil samples by inductively coupled plasma-mass spectrometry: Microwave acid 
digestion versus aqua regia extraction. Analytica Chimica Acta, 543, 117-123.

Ministerio de Ambiente Panamá (2012). Mapa de Cobertura y Uso de la Tierra, en la República de Panamá (p. 1). Retrieved March 10, 2019 from, https://www.unredd.net/ index.php?view=download\&alias=14898-mapa-decobertura-boscosa-y-uso-de-la-tierrainformefinal\&category_slug=sistema-satelitalmonitoreo\&option=com_docman \&Itemid=134 .

Mykolenko, S., Liedienov, V., Kharytonov, M., Makieieva, N., Kuliush, T., Queralt, I., Marguí, E., Hidalgo, M., Pardini, G., \& Gispert, M. (2018). Presence, mobility and bioavailability of toxic metal(oids) in soil, vegetation and water around $\mathrm{a} \mathrm{Pb}-\mathrm{Sb}$ recycling factory (Barcelona, Spain). Environmental Pollution, 237(2018), 569-580. https://doi. org/10.1016/j.envpol.2018.02.03

Nadimi-Goki, M., Wahsha, M., Bini, C., Kato, Y., Vianello, G., \& Antisari, L. (2014). Assessment of total soil and plant elements in rice-based production systems in NE Italy. Journal of Geochemical Exploration, 147(2014), 200-214. https://doi.org/10.1016/j.gexplo.2014.07.008

Nelson, C., \& Ganoza, J. (1999). Mineralización de oro en la franja aurífera de Veraguas, Panamá. Revista Geológica de América Central, 2(22), 87-100. https://doi.org/10.15517/ rgac.v0i22.8589

NRC. (2001). National research council, nutrient requirements of dairy cattle: Seventh revised (p. 381). The National Academies Press.

Palansooriya, K., Shaheen, S., Chen, S., Tsang, D., Hashimoto, Y., Hou, D., Bolan, N., Rinklebe, J., \& Ok, Y. (2020). Soil amendments for immobilization of potentially toxic elements in contaminated soils: A critical review. Environment International, 134, 105046. https://doi.org/10.1016/j. envint.2019.105046

Pan, Y., Peng, H., Xie, S., Zeng, M., \& Huang, C. (2019). Eight elements in Soils from a Typical Light Industrial City, China: Spatial distribution, ecological assessment, and the source apportionment. International Journal of Environmental Research and Public Health, 16(14), 2591. https:// doi.org/10.3390/ijerph16142591ss

Pareja-Carrera, J., Martínez-Haro, M., Mateo, R., \& RodríguezEstival, J. (2021). Effect of mineral supplementation on lead bioavailability and toxicity biomarkers in sheep exposed to mining pollution. Environmental Research, 196(2021), 110364. https://doi.org/10.1016/j.envres.2020. 110364

Pérez-López, R., Álvarez-Valero, A., Nieto, J., Sáez, R., \& Matos, J. (2008). Use of sequential extraction procedure for assessing the environmental impact at regional scale of the São Domingos Mine (Iberian Pyrite Belt). Applied Geochemistry, 23, 3452-3463.

Rajatheja, M., Chandrajit, R., Bentota, A., \& Jayasinghe, G. (2021). A comparative assessment of trace element accumulation in native an improved rice (Oryza sativa L.) varieties grown under different conditions of fertilizer application. Biological Trace Element Research, 199, 1153-1160. https://doi.org/10.1007/s12011-020-02213-9

Rather, B., Masood, A., Sehar, Z., Majid, A., Anjum, N., \& Khan, N. (2020). Mechanisms and role of nitric oxide in phytotoxicity-mitigation of copper. Frontiers in Plant Science, 11, 675. https://doi.org/10.3389/fpls.2020.00675
Rogival, D., Scheirs, J., \& Blust, R. (2007). Transfer and accumulation of metals in a soil-diet-wood mouse food chain along a metal pollution gradient. Environmental Pollution, 145(2), 516-528. https://doi.org/10.1016/j. envpol.2006.04.019

Rothenberg, S., Feng, X., Dong, B., Shang, L., Yin, R., \& Yuan, $X$. (2011). Characterization of mercury species in white and brown rice (Oryza sativa L.) grown in water-saving paddies. Environmental Pollution, 159, 1283-1289. https://doi.org/10.1016/j.envpol.2011.01.027

Sahuquillo, A., López-Sánchez, J., Rubio, R., Rauret, G., Thomas, R., Davidson, C., \& Ure, A. (1999). Use of a certified reference material for extractable trace metals to assess sources of uncertainty in the BCR three-stage sequential extraction procedure. Analytica Chimica Acta, 382(1999), 317-327.

Santos, E., Abreu, M., \& Magalhães, M. (2016). Cistus ladanifer phytostabilizing soils contaminated with non-essential chemical elements. Ecological Engineering, 94(2016), 107-116. https://doi.org/10.1016/j.ecoleng.2016.05.072

Shabbir, Z., Sadar, A., Shabbir, A., Abbas, G., Shamshad, S., Khalid, S., Murtaza, G. N., Dumat, C., \& Shahid, M. (2020). Copper uptake, essentiality, toxicity, detoxification and risk assessment in soil-plant environment. Chemosphere, 259, 127436. https://doi.org/10.1016/j. chemosphere. 2020.127436

Shtangeeva, I., Viksna, A., Bertins, M., Ryumin, A., \& Grebnevs, V. (2020a). Variations in the concentrations of macro- and trace elements in two grasses and in the rhizosphere soil during a day. Environmental Pollution, 262(2020), 114265. https://doi.org/10.1016/j.envpol.2020. 114265

Shtangeeva, I., Viksna, A., Bertins, M., \& Grebnevs, V. (2020b). Geochemical (soil) and phylogenetic (plant taxa) factor affecting accumulation of macro and trace- elements in three natural plant species. Environmental Geochemistry and Health, 2020(42), 209-219. https://doi.org/10.1007/ s10653-019-00337-z

Smith, A., Lingas, E., \& Rahman, M. (2000). Contamination of drinking-water by arsenic in Bangladesh: A public health emergency. Bulletin of the World Health Organization, 78(9), 1093-1103.

Sun, Z., \& Chen, J. (2018). Risk assessment of potentially toxic elements (PTEs) pollution at a rural industrial wasteland in an abandoned metallurgy factory in North China. International Journal of Environmental Research and Public Health. https://doi.org/10.3390/ijerph15010085

UN (2015). World Population Prospects 2015. United Nations, Department of Economic and Social Affairs, File POP/2: Average annual rate of population change by major area, region and country (Vol. 1, pp. 1950-2100).

USEPA (1989). Risk Assessment Guidance for Superfund, Vol. 1: Human Health Evaluation Manual, Part A.; Interim Final; Office of Emergency and Remedial Response. US Environmental Protection Agency: Washington, DC, USA, (1989), Retrieved April 12, 2021 from, https://www.epa. gov/sites/production/files/2015-09/documents/rags_a.pdf.

USEPA (2001). Risk Assessment Guidance for Superfund, Vol. 3: Part A, Process for Conducting Probabilistic Risk Assessment. Office of Emergency and Remedial Response, US Environmental Protection Agency: Washington, DC, 
USA, Retrieved April 12, 2021 from, https://www.epa.gov/ sites/production/files/2015-09/documents/rags3adt_ complete.pdf.

USEPA. (2007). Method 3051a microwave assisted acid digestion of sediments, sludges, soils, and oils. Revision, 1(2007), 30.

USEPA (2019). Regional Screening Level (RSL) Summary Table (TR = 10-6, HQ = 1), April 2019. US Environmental Protection Agency: Washington DC, USA, Retrieved April 12, 2021 from, https://semspub.epa.gov/src/document/HQ/ 199432.

USEPA (2011). Exposure Factors Handbook, Edition 2011, EPA/600/R-09/052F. US Environmental Protection Agency; National Center for Environmental Assessment: Washington, DC, USA, Retrieved April 13, 2021 from, http://ofmpub.epa.gov/eims/eimscomm.getfile?p_ download_id=522996.

Wang, G., Su, M., Chen, Y., Lin, F., Luo, D., \& Gao, S. (2006). Transfer characteristic of cadmium and lead from soil to the edible parts of six vegetable species in southeastern China. Environmental Pollution, 2006(144), 127-135. https://doi.org/10.1016/j.envpol.2005.12.023

WHO. (2005). Dietary exposure assessment of chemicals in food; Report of Joint FAO/WHO Consultation. WHO Library.
WHO (2008). Guideline for Drinking Water Quality, 3rd ed., Incorporating First and Second Addenda. World Health Organization: Geneva, Switzerland, Volume 1 Recommendations, 2008.

Yada, M., Melo, W., \& Melo, V. (2020). Trace elements in soil, plant and grain of corn plants cultivated in Latosols after sixteen years with application of sewage sludge. Engenharia Sanitária e Ambiental. https://doi.org/10.1590/ S1413-41522020150124

Zhang, J., Yang, R., Chen, R., Peng, Y., Wen, X., \& Gao, L. (2018). Accumulation of heavy metals in tea leaves and potential health risk assessment: A case study from Puan County, Guizhou Province, China. International Journal of Environmental Research and Public Health, 15(1), 133.

Zhuang, P., McBride, M., Xia, H., Li, N., \& Li, Z. (2009). Health risk from heavy metals via consumption of food crops in the vicinity of Dabaoshan mine, South China. Science of the Total Environment, 407(5), 1551-1561. https://doi.org/ 10.1016/j.scitotenv.2008.10.061

Publisher's Note Springer Nature remains neutral with regard to jurisdictional claims in published maps and institutional affiliations. 